NBER WORKING PAPER SERIES

\title{
THE IMPORTANCE OF FAMILY INCOME IN THE FORMATION AND EVOLUTION OF NON-COGNITIVE SKILLS IN CHILDHOOD
}

\author{
Jason Fletcher \\ Barbara L. Wolfe \\ Working Paper 22168 \\ http://www.nber.org/papers/w22168
NATIONAL BUREAU OF ECONOMIC RESEARCH
1050 Massachusetts Avenue
Cambridge, MA 02138 \\ April 2016
}

The authors thank Elaine Liu, Elise Gould, and Jane Waldfogel for helpful comments. Fletcher thanks the Robert Wood Johnson Foundation Health \& Society Scholars program for its financial support. The results in this paper are not the result of for-pay consulting. The views expressed herein are those of the authors and do not necessarily reflect the views of the National Bureau of Economic Research.

NBER working papers are circulated for discussion and comment purposes. They have not been peer-reviewed or been subject to the review by the NBER Board of Directors that accompanies official NBER publications.

(C) 2016 by Jason Fletcher and Barbara L. Wolfe. All rights reserved. Short sections of text, not to exceed two paragraphs, may be quoted without explicit permission provided that full credit, including $(\odot$ notice, is given to the source. 
The Importance of Family Income in the Formation and Evolution of Non-Cognitive Skills

in Childhood

Jason Fletcher and Barbara L. Wolfe

NBER Working Paper No. 22168

April 2016

JEL No. I21,J24

\begin{abstract}
Little is known about the relationship between family income and children's non-cognitive (or socio-emotional) skill formation. This is an important gap, as these skills have been hypothesized to be a critical link between early outcomes and adult socioeconomic status. This paper presents new evidence of the importance of family income in the formation and evolution of children's non-cognitive skills using a recent US panel dataset that tracks children between grades K-5. Findings suggest an important divergence in non-cognitive skills based on family income that accumulates over time and does not seem to be explained by children's health status differences.
\end{abstract}

Jason Fletcher

University of Wisconsin-Madison

La Follette School of Public Affairs

1225 Observatory Drive

Madison, WI 53706

and NBER

jfletcher@lafollette.wisc.edu

Barbara L. Wolfe

1225 Observatory Dr

University of Wisconsin

Madison, WI 53706

and NBER

BWolfe@wisc.edu 
The Importance of Family Income in the Formation and Evolution of Non-Cognitive Skills in Childhood

"Genius is 1 percent inspiration and 99 percent perspiration." Thomas Edison

\section{Introduction:}

Parental socio-economic status is an important determinant of a child's future socioeconomic status (SES), and the pathway to this link is thought to be some combination of genes (inheritance), parental time investments in the child weighted by the quality of that time, access to marketed goods and services, community resources and other aspects of the home environment. The intermediate outcome of this combination of factors is a variety of forms of human capital, and ones most frequently studied are health and cognitive development (years of schooling and test scores, for example.) Numerous papers have been written on poor-nonpoor gaps in health and school performance among children but far fewer on non-cognitive gaps by SES, even though evidence is accumulating that these non-cognitive skills may also be critically important as determinants of future success.

Beginning primarily with work by Case et al. (2002), economists and other social scientists have focused on the childhood origins of the large differences in health and economic status during adulthood. This work showed that the relationship between family income and child health grows stronger as children age, likely in part due to the cumulative effects of living in low-income households who face associated stress, more frequent health shocks and limited access to health care. This research has spawned a large set of papers that show that these empirical relationships can be found across countries with very different welfare and health 
systems as well as across time periods (Currie and Stabile 2003, Condliffe and Link 2008,

Khanama et al. 2009, Propper et al. 2007; See Fletcher and Wolfe 2014 for review).

A relatively less studied but related question is whether similar patterns exist in other areas of childhood development, such as so-called "non-cognitive" (socio-emotional/

personality) skills. As opposed to cognitive skills, which are measured by scores on tests such as reading, math, history or science as well as IQ tests, noncognitive skills are both more difficult to measure and there is less agreement on which ones are important. ${ }^{1,2}$ The limited agreement on both the conceptualization of noncognitive skills and inconsistent measurement may contribute to the lack of attention by economists.

The limited study of non-cognitive or socio-emotional skills is a potentially important omission since socio-emotional skills may be a critical factor in predicting a range of important adult outcomes. This domain of skill formation has also become the subject of intense study in economics in recent years ${ }^{3}$. For example, work with the NLSY (Heckman, Sixtrud and Urzua 2006) found that locus of control and self-esteem were likely critical in determining years of schooling ${ }^{4,5}$. In a recent overview paper, Brunello and Schlotter (2011) suggest that noncognitive skills are important as determinants of these skills but also of cognitive skills more

\footnotetext{
${ }^{1}$ For adults, economists have tended to use a five-factor model related to personality psychology: conscientiousness, emotional stability, agreeableness, extraversion and autonomy (Nyhus and Pns, 2005). These overlap but are not entirely identical to the big five among psychologists who use "OCEAN"; openness to experience, conscientiousness, extraversion, agreeableness and neuroticism (similar to emotional stability). See John 1990. ${ }^{2}$ For children, while there is some overlap (independence for example), there is somewhat more emphasis on maturity, learning skills, motivation, attention, patience, and the ability to act appropriately (externalizing and internalizing behaviors)(see ter Weel 2008 and related papers in the symposium covered by the 2008 volume of the Journal of Human Resources).

${ }^{3}$ Heckman stated..."the preoccupation with cognition and academic smarts as measured by test scores to the exclusion of social adaptability and motivation causes a serious bias in the evaluation of many human capital interventions.." 1999, p. 1 Heckman J, (1999), Policies to Foster Human Capital, NBER Working Paper 7288 ${ }^{4}$ Their results suggest that going from the $25^{\text {th }}$ to $75^{\text {th }}$ percentile in the distribution of non-cognitive skills is associated with a 25 percentage point increase in the probability of having graduated college by age 30 ${ }^{5}$ Fletcher (2012) shows evidence that the personality trait of extroversion is positively related to labor market outcomes. A recent paper (Savelyev, 2012) also documents the importance of one particular noncognitive skill, conscientiousness, as a determinant of life expectancy for men.
} 
generally and cite evidence of the importance of this under-researched area of human capital.

They also stress the very limited knowledge of the determinants of noncognitive skills and raise (but do not answer) the question of whether these are malleable and might respond to interventions.

The objective of this paper is to increase our knowledge of the ways in which family socioeconomic status, in particular income, influences the acquisition of noncognitive skills as a child grows up. We study this issue for a particular set of noncognitive skills; a priori we have no expectation that the tie from parental income to noncognitive skills will be similar, much less the same, across all noncognitive skills. In supplementary analysis, we also attempt to ascertain the links from noncognitive skills to cognitive skills and/or whether noncognitive skills appear to be influenced by earlier cognitive skills in order to further understand the importance and determinants of the various non-cognitive measures in the data.

Increasing our understanding of the factors critical in explaining the formation of socioemotional skills during childhood and also whether the divergence in these skills is in part due to family resources is our focus. Evidence on this question may provide clues on whether policies that increase the resources of low income households may have positive effects on children's socio-emotional development, though the descriptive results in this paper serve only as a first step in this direction. .

This paper uses a recent panel study from the US that tracks a national sample of children between Kindergarten and $5^{\text {th }}$ grade to examine the associations between family income and a broad set of measures of children's socio-emotional skill development. The panel nature of the data allows measures of permanent family income to be assessed and the sampling structure of the data allows the inclusion of neighborhood measures of human capital, including income. The 
rich set of survey questions enables us to separate the potential direct effects of family income on skills with the indirect effects that might operate through children's health. In particular, we hypothesize that children growing up in homes with greater income will 1) have higher socioemotional (noncognitive) skills and 2) that these effects will accumulate over time such that the tie between family income and each socio-emotional scale variable will increase as the child ages. The results from the analysis suggest important deficits in socio-emotional skills at schoolentry for children from low-income households that grow as children age. The deficits are apparent for all measured skills and each skill has a unique trajectory over time, though by $5^{\text {th }}$ grade the original differences by family income have often doubled or tripled in size. We also find very little evidence that the deficits are driven by differences in children's health.

\section{Background Literature}

Although there is a substantial body of work in psychology and other allied disciplines exploring aspects of the determinants and consequences of non-cognitive skills, much less research exists within economics. What is available is relatively recent and has focused on the consequences of non-cognitive skills, typically on labor market outcomes or schooling outcomes. In contrast, virtually no research in the economics literature has focused on understanding the determinants of non-cognitive skills or their evolution using panel data. Broadly, consequences of poor non-cognitive skills have been found in several areas of the labor market, including job performance, wages, and occupational choice, as well as in educational outcomes for children of all ages. Additionally, some economics research has attempted to understand the potential complementarities between non-cognitive skills and cognitive skills in these labor market outcomes and have broadly shown extensive complementarity. 
Amongst the early economics study of the importance of non-cognitive skills was the study of general education degrees (or GED) recipients (Heckman and Rubinstein 2001), which provided evidence that while GED recipients have cognitive test scores equal to those of high school graduates, on average, they only have earnings equal to those of high school dropouts. One explanation for this pattern is that GED recipients tend to have limited non-cognitive skills. It is this lack of skills that prevents them from being successful in the military, the labor force and in personal relationships.

With this evidence on labor market outcomes, there has also been interest in whether educational attainments and health are affected directly. For example, in an early examination, Coleman and DeLeire (2003) use a measure of locus of control $^{6}$ to explore the importance of this particular noncognitive trait in influencing years of schooling. More recently, a broad overview paper on personality characteristics (a variety of noncognitive factors) and their importance for years of schooling found that conscientiousness was an important predictor of both grades and years of schooling, while openness to experience was important for years of schooling (Borghans et al 2006). This paper reports on a meta analysis from the psychology literature which looks at evidence on the importance of personality traits in explaining job performance, health and schooling success. This review suggested that while IQ was a more important factor than any of the big 5 personality traits, conscientiousness was an important factor for college grades and years of schooling. Indeed, conscientiousness was the single most important predictor of life expectancy (more important than IQ), but the two were reversed in terms of predicting job performance. Conscientiousness was found to be important for all jobs while IQ was most

\footnotetext{
${ }^{6}$ Locus of control refers to the extent to which individuals believe that they can control events that may affect them. This measure ranges from internal locus of control, where individuals believe they generally have control over their lives, and external locus of control, where individuals believe that others (the environment, a higher power, etc.) control their outcomes.
} 
important for complex jobs, including professors, scientists and senior managers (Schmidt and Hunter 2004). Coneus, Gernandt and Saam (2009) also explored this issue using the German Socio-economic panel and found an important role for noncognitive skills in reducing the probability of dropping out of school and that the importance of these skills increased with age.

Further decoupling the importance of non-cognitive skills for education and labor market success, Judge and Hurst (2007) showed that positive self reports of self esteem, internal locus of control, and emotional stability usefully predict future income over and above both grades and years of schooling using data for the U.S. from NLSY 1979. In essence they find that more schooling and better grades are important for those with positive personality traits but do not pay off otherwise. They speculate that those who rate high on these traits search for challenging and rewarding jobs, persist on difficult tasks, and are motivated to tackle any failure.

This emerging evidence on the importance of non-cognitive skills on adult socioeconomic outcomes then leads to the question of how early in life these skills appear to be important determinants of outcomes. A study using British data attempted to understand the importance of cognitive and noncognitive skills on years of schooling (Carneiro, Crawford and Goodman 2006). Noncognitive skills were measured by social adjustment at age 11 and the authors found that children who had higher levels of social adjustment at age 11 were more likely to remain in school past age 16 and to get a higher degree. They also found that the influence of higher cognitive skills on these two outcomes is low if social adjustment is low but important if social adjustment skills are high, again suggesting interactive effects.

With these findings suggesting the importance of the early development of non-cognitive skills on later life outcomes, a few tentative policy-related findings have also emerged. For example, Cunha et al. (2006) suggest that much of the effectiveness of early childhood 
interventions seem to come from increasing noncognitive skills and motivation. The authors suggest that while IQ is fairly stable after age 10, self-control, motivation and other traits are malleable at later ages (see also Heckman 2000). ${ }^{7,8}$

This emerging evidence of the importance of non-cognitive skills for adolescent and adult socioeconomic outcomes as well as the preliminary work suggesting that these skills are malleable for school-aged children suggest a need to further document the critical determinants of non-cognitive skills during childhood. ${ }^{9}$ Indeed, there is very little evidence of the links between family income and socioemotional skills development during childhood ${ }^{10}$. One of the few examinations in the literature was done by Violato et al. (2011), utilizing data from the UK. The authors find substantial links that are "explained" by several family processes such as parental stress and investments in children. However, these authors focus on younger aged children (through age 5), while the current paper traces outcomes between the ages of 6 and $12 .{ }^{11}$

\section{$\underline{\text { Data }}$}

In this paper we use the Early Childhood Longitudinal Study-Kindergarten Cohort data (ECLS-K). These panel data were collected beginning in 1998/99 and follow children from Kindergarten through $5^{\text {th }}$ Grade (in spring of 2004), so that the ages of the children span from

\footnotetext{
${ }^{7}$ Though, as one would expect, there is also great persistence in these measures during childhood. See Morgan et al. 2009 for evidence of the persistence of externalizing and internalizing behaviors between ages 6-12.

${ }^{8}$ This type of evidence is also consistent with evidence using animals (see Knudson et al. 2006 and Suomi 1999), where experimental manipulation of the resources early in development are tracked to show relationships with measures of motivation or other "non-cognitive skills".

${ }^{9}$ Additionally, Gupta and Simonsen (2010) provide evidence that child care quality influences non-cognitive outcomes for some children at age seven using Danish data.

${ }^{10}$ There is more conclusive evidence of the impacts of family income on cognitive skills. For example, see Dahl and Lochner (2012) for one such analysis.

${ }^{11}$ The data also contain a limited number of socioemotional skills and these skills are often not assessed the same way as children age. The authors do include a temperament scale for 9-month old children and a behavior scale for ages 3 and 5 .
} 
roughly 6 to 12 years old ${ }^{12}$. The core survey contains reports by parents, children, and teachers in a variety of standard domains, though the study focuses on educational experiences of schoolage children. ${ }^{13}$ Since income is measured at each wave, we construct a measure of "permanent income" that averages the income measures up to the current survey grade. ${ }^{14}$ In addition to standard sociodemographic and education questions, the study collected direct cognitive and noncognitive assessments in each wave, including reading and mathematics test scores, and social/emotional scales. The social and emotional development assessments were created to focus on aspects of social competence that include social skills (self control, cooperation) and problem behaviors (impulsivity and aggression). These assessments were formed based on reports of both teachers and parents, though we focus on teacher reports in this paper ${ }^{15}$. The social ratings scale (SRS) is an adaptation of the Social Skills Rating System developed by Gresham and Elliott (1990), where frequency scales are used. The behaviors are reported as exhibited: 1 never; 2 occasionally/sometimes; 3 regularly but not all the time; and 4 most of the time.

The scales included in the data are meant to capture multiple domains of socio-emotional skills and are based on work by Gresham \& Elliott (1990). The primary aggregated scales are under the umbrella of a set of Social Ratings Scales, with labels including "Interpersonal Skills", "Externalizing Symptoms", "Internalizing Symptoms”, "Self Control Skills" and "Approaches to

\footnotetext{
${ }^{12}$ While the panel follows children through $8^{\text {th }}$ grade, there are no teacher-reported socio-emotional measures collected during the $8^{\text {th }}$ grade wave.

${ }^{13}$ According to the ECLS, trained evaluators assessed children in schools while parents were surveyed by phone. Teachers and school administrators completed questionnaires at their schools. Details on assessments can be found at http://nces.ed.gov/ecls/kinderassessments.asp.

${ }^{14}$ For example, the measure of permanent income for $3^{\text {rd }}$ graders is the average of the income reports for Kindergarten, First Grade, and Third Grade for each student. This has the disadvantage of increasing in accuracy as the child ages. We prefer it to permanent income across all grades as that measure would include measures after the observed measure of noncognitive skills.

${ }^{15}$ Teacher assessments are likely to be comparable, at least across children in the same classroom, than those of individual parents. Teacher assessments may be relative within their current and past classrooms; nevertheless we view them as likely more consistent and informative than parent's assessments, which are based on a far smaller set of children.
} 
Learning." The subcomponents of the Approaches to Learning scale have been released to researchers through a separate contractual agreement and include the following items: "Keeps belongings organized"; "Shows eagerness to learn new things"; "Works independently"; "Easily adapts to changes in routine"; "Persists in completing tasks"; and "Pays attention well".

Table 1 presents summary statistics for grades Kindergarten and $5^{\text {th }}$ grade and include all children present in the sample for each grade. The social ratings scales range from 1-4, but since they are averages of many sub-scales, they are "continuous". The scales do not substantially increase between Kindergarten and $5^{\text {th }}$ grade suggesting that teachers may treat them as relative rather than absolute skills. Special education rates increase from 4 to $10 \%$ between $\mathrm{K}$ and $5^{\text {th }}$ grade. The similarities in the observable characteristics (e.g. maternal education, birth weight) in the table between Kindergarten and $5^{\text {th }}$ grade suggest that attrition issues are not substantial. Table 2 further divides the Approaches to Learning scale into its relevant subscales. Since these sub-scales include values of 1-4, we also provide the descriptive distributions of the sub-scales in the sample. Many scales are quite stable between Kindergarten and $5^{\text {th }}$ grade, though most show slight decreases, with the "eager to learn" subscale exhibiting the most prominent decline as these children age.

Below we test our hypothesis that as children age there is an increasing tie between family income and the full set of available social-emotional skill indices. Thus we hypothesize that the disparity in noncognitive skills increases over the childhood period with children in higher income families increasingly being more advantaged. Our hypothesis is consistent with most evidence examining childhood health and some evidence regarding cognitive outcomes (e.g. Case et al. 2002). Our prior work using the same data set we use here provided evidence of the steepening of the income gradient with regard to health (Fletcher and Wolfe, 2011). We 
believe that the same link will exist between income and noncognitive skills. These skills are likely to be sensitive to stress, family stability, parents' emotional status and safety in one's neighborhood. All of these are tied to income. All of them have some likely overlap in the way they influence health ${ }^{16}$. It is on this basis that we formed our hypothesis. In particular we hypothesize that children growing up in homes with greater income will 1) have higher socioemotional (noncognitive) skills and 2) that these differences will increase over time such that the tie between family income and each socio-emotional scale variable will be greater as the child ages. The basis for our hypothesis is that children in lower income families are likely to experience more stress, more family instability, see fewer successful role models in their neighborhood, and may also be more exposed to environmental hazards, among other experiences of disadvantage. ${ }^{17}$

To test these hypotheses, we employ a standard empirical human capital model:

$$
S_{i t}=\beta_{0}+\beta_{1} \log \left(Y_{i t}\right)+\delta X_{i t}+\varepsilon_{i t}
$$

where $S_{i t}$ the skill of interest for child $i$ at time $t$ is a function of family income and a vector of demographic control variables including age, sex, race, parental characteristics such as education, age, and marital status. We expect that the coefficient on log Y will be positive in our regression estimates for each grade. We also expect that the coefficient on log Y will be larger at higher grades. In some specifications, we add measures of child health, such as birth weight and self (mother) reported health status to potentially separate the direct effects of family income on

\footnotetext{
${ }^{16}$ In Fletcher and Wolfe 2014 we provide evidence on the income gradient of health where the coefficient on income is increasing as a child ages (that is, is in a higher grade). All of the coefficients on log family income are significant at the 1 percent level. The other control variables all have the expected signs but few are statistically significant at standard levels: the exceptions are racial dummy variables and maternal education. The increasing tie between income and health can be substantiated by converting the coefficients into marginal effects.

${ }^{17}$ Recent evidence shows that gray matter in areas of the brain such as the prefrontal lobe, which is important for executive function or non cognitive functions, exhibit a maturation gap among children growing up in poor families. See Pollak et al 2015. That work shows this exists even for children of low income parents who are well-educated.
} 
skill development from the indirect effects that may operate through child health including early child health (Case et al. 2002). We expect that using permanent income (income measured in all years prior and contemporary with the time noncognitive skills are measured) will show a steeper tie between income and noncognitive outcomes than the use of single-year current income. This is because noncognitive skills develop over time and so will be influenced by prior income as well as current income and because permanent income is a better measure of family income. We conduct a test of this hypothesis to try and separate the effect of less noise in the measure from a cumulative effect. Specifications use OLS regression analysis, though the aggregated scales are continuous and the sub-scales take values $1-4$, as described above.

\section{$\underline{\text { Results }}$}

In all analyses that follow, we use the $5^{\text {th }}$ grade longitudinal sample weights provided in the ECLSK. We begin by examining whether there are differences in socioemotional skills by family income as children enter school. In Table 3, we present the income differences in our set of socioemotional skills at Kindergarten. The first three measures of socioemotional skills, approaches to learning, interpersonal skills and self-control are all positive indicators; the last two, externalizing and internalizing are negative indicators. All five show the expected relationship to a family's permanent income at Kindergarten entry. Externalizing appears somewhat less robustly tied to family income - the statistical significance is only at the 10 percent level. Overall these simple relationships suggest that children from lower income families begin school with disadvantages in terms of their noncognitive skills and that this holds across multiple measure of skills. We expect these differences to grow, but it is possible that 
once children spend time in school, differences tied to parental resources could be reduced or even eliminated.

In Table 4, we begin our examination of the determinants of trajectories of socioemotional skills by focusing on the Approaches to Learning scale ${ }^{18}$. Our focus is on the tie to family income. We find substantial evidence that children living in higher income families have higher scores on approaches to learning. And the general pattern is one of increasing advantage as the children age though the pattern is primarily observed between $\mathrm{K}$ and $5^{\text {th }}$ grade. The results (coefficients) show that the tie from income to approaches to learning more than doubles from kindergarten to the fifth grade. ${ }^{19}$ In terms of other included variables, males have lower scores on this scale than females—a nearly $1 / 3$ standard deviation difference that grows as the children age. Black students enter school with lower scores on this scale and this difference also grows to over $1 / 10^{\text {th }}$ of a standard deviations. In contrast, Hispanic students have a relative advantage that fluctuates over time in comparison to whites. Children with parents with higher education also have small and persistent advantages on this skill measure.

Table 5 shows these results are quite similar for each of the subscales: attention, organized, eager to learn, independent, adaptable and persistence. All of these exhibit an analogous pattern in terms of the tie to family income. The ties are strongest for organization and persistence. We provide formal tests of statistical differences in these tables; typically the differences between Kindergarten and first grade are not statistically significant nor are the differences between $3^{\text {rd }}$ and $5^{\text {th }}$ grade, though there are typically substantial differences between Kindergarten and $3^{\text {rd }}$ and/or $5^{\text {th }}$ grades.

\footnotetext{
${ }^{18}$ Recall that the scale includes measures such as: "Keeps belongings organized"; "Shows eagerness to learn new things"; "Works independently"; "Easily adapts to changes in routine"; "Persists in completing tasks"; and "Pays attention well".

${ }^{19}$ The exception to this trend is the result for grade 1, but this too shows a positive tie between parental income and the approaches to learning scale.
} 
Table 6 presents results for several additional indices of socio-emotional behavior, selfcontrol, interpersonal skills, and mental health outcomes and special education status. Consistent with the results for approaches to learning in Table 4, we find sizeable differences in many of the skill indices by family income, and these gaps double in size as children age from kindergarten through $5^{\text {th }}$ grade. For mental health outcomes, we examine internalizing and externalizing scales. Internalizing scales are more akin to measures of depression and anxiety whereas externalizing measures are typically thought of as emotional behavioral disorders and conduct disorders. We find relatively large differences in the evolution of these scales as children age. Children from poorer families have higher externalizing scores at school entry, but the disparity is relatively constant beginning with first grade and continuing through fifth grade. In contrast, children from poorer families also enter Kindergarten with higher internalizing score, and this gap triples by $5^{\text {th }}$ grade. We find little evidence of initial differences in special education status by family income, though by $5^{\text {th }}$ grade family income is a strong predictor of placement. Finally, we present a summary measure of all the socioemotional skills in the data using factor analysis and again find large initial differences in these skills at Kindergarten entry that grow substantially by fifth grade.

\section{$\underline{\text { Robustness and Potential Mechanisms }}$}

We consider several additional examinations of potential mechanisms that may account for a portion of the patterns we find in the data. We first ask whether it is family income that directly influences non-cognitive skills or whether it is the purchase of attendance at schools with 
peers who have higher noncognitive skills ${ }^{20}$. The results presented in Table 7 suggest that family income plays a direct role but that part of the influence may be through "purchasing" better school peers, which may occur through paying for private school tuition or, more commonly, through purchasing housing in areas with "better schools" (defined here according to average noncognitive ability of students attending the school). For most estimates and nearly all of our measures of noncognitive skills, including, in particular, the combined factor, self control, organization, eager to learn, interpersonal skills, adaptability independent and approaches to learning, the direct influence of family income is positive, it increases as the child ages, and the family level gradient is reduced by the inclusion of the average noncognitive factor of other classmates sampled in the ECLS- $\mathrm{K}^{21}$.

Interestingly, for many of these outcomes the results for $5^{\text {th }}$ grade differ and suggest that when the school-level noncognitive factor is included, the influence of family income actually increases. These results then provide evidence of the robustness of the income gradient of noncognitive skills and also suggest that school composition in terms of these skills may be most important in the earliest grades. This is consistent with literature on the importance of readiness to learn in the earliest grades, a philosophy tied to Head Start funding. ${ }^{22}$ It is also consistent with findings on the Perry Pre-School project, which did not appear to increase IQ, though it did improve scores and personality traits. (Heckman et al 2010).

\footnotetext{
${ }^{20}$ We recognize that this approach faces the difficulties identified by Manski (1993) as the reflection problem. However we are less interested in how the school group influences the individual but rather whether inclusion of the group "behaviors" reduces the influence of family income. Given this we proceed but with caution.

${ }^{21}$ An alternative explanation of these findings is that, since the socioemotional skill measures are reported by the teacher for all children in the classroom, we are in part controlling for teacher styles of reporting and not objective measures of skills.

${ }^{22}$ When we run a set of similar estimates using test scores as the outcome and a test score factor for the school we find a somewhat similar pattern. In these specifications, there is a strong tie between family income and performance on tests (math, reading or a combination) that is increasing over grades $\mathrm{K}$ to $8^{\text {th }}$ grade. The inclusion of the school mean test score factor reduces the influence of income slightly with the greatest reduction in Kindergarten (by more than half) but only by about $10 \%$ by grades 5 and 8 . Results are available from the authors by request.
} 
A second examination we include is a focus on the potential links between child health and socioemotional skills and family income. As we noted above, there is substantial evidence of strong links between family income and childhood health across many countries and time periods, including the dataset used in this study (see Fletcher and Wolfe 2014). Thus, it could be the case that an important channel linking family income and children's non-cognitive skills is through this established health channel. Our results in Table 8 suggest that child health could play a role in the process. For about half of our socioemotional measures, we find statistical differences in specifications that control for lagged child health compared with our baseline results. In general, controlling for health reduces the links between family income and socioemotional skill by $5^{\text {th }}$ grade, though these reductions do not change the qualitative results we present earlier and are typically in the $15-30 \%$ range of reductions in the socioemotional skill gradients.

\section{Robustness: Testing alternative measures of income}

In our core estimates, we used permanent family income defined as the average income over all years up to and including the year the child is being observed. But there are alternative definitions that can be used as well - current income (year t income), a rolling average of three separate observations of income (such that income in kindergarten is the average of kindergarten, first and third grades, and so on); the latter approach has the advantage of consistency in removing "noise" in our measure of income. ${ }^{23}$ We explore these in our tests of robustness in Appendix Table B. Both of these compare results for grades K, 1, 3 and 5 for each of these three measures of family income for all of our dependent variables. The other variables in the regressions remain unchanged.

\footnotetext{
${ }^{23}$ We note however that the standard deviations of our various measures of income do not differ substantially.
} 
The results overall suggest a good deal of consistency across these measures of income. Although in principle the measure of permanent income has the disadvantage of including income flows following the measurements of socioemotional skills, the alternative measures of income each suffer disadvantages. Contemporaneous income (Measure 2 in the table) is predicted to lead to attenuated estimates because of its noise as a single measure. The use of rolling averages (Measures 3 and 4) have the advantage that they do not include "future" income but have the disadvantage of becoming more precise as children age (we only have one measure of income for Kindergarteners but four measures for $5^{\text {th }}$ graders). With these issues outlined, the practical impact of the various disadvantages of each measure appears to be small for our qualitative results. Indeed, as shown in Appendix Table B, all of our results are substantially robust across the four measures of income, with the Kindergarten results far below those for fifth grade. The final column reports the p-values of a joint test of differences in these coefficients based on income measurement compared with the baseline measures we use in the main text; we only find one statistical difference and the even then the coefficients are qualitatively the same. Figure 1 captures the differences. ${ }^{24}$

\section{Robustness: Child Fixed Effects}

While a substantial pathway linking family income with child noncognitive scores does not appear to be primarily through school (and peer) selection, we may be capturing intergenerational links between parent and child noncognitive skills that could be from shared genetic backgrounds. To partially examine this issue, we estimated a pooled set of results using child fixed effects. For a number of reasons, we consider these results as a check of robustness

\footnotetext{
${ }^{24}$ Another robustness check we present in Appendix Table $\mathrm{C}$ is whether using an unbalanced sample differs with the results using a balanced sample. Although statistical tests uncover differences in the coefficients in a few cases, the qualitative results do not change using the balanced sample.
} 
but otherwise not conclusive nor our preferred specifications. Adding interactions between family income and survey wave (i.e. grade) is the way we examine whether the income effects are driven by time-invariant factors. ${ }^{25}$ These specifications have some disadvantages, including the need to use contemporaneous measures of income and the reduction in both exogenous and endogenous variation in the processes we seek to understand. In particular, in the fixed effects model, we remove the "permanent" component of income, which is the primary focus of this article; in addition, measurement error in family income and in the socioemotional measures could attenuate our results without signaling an important role for intergenerational transmission of socioemotional skills tied to income. These analyses also do not adequately take into account the dynamic effects ${ }^{26}$ of income on socioemotional skill accumulation, which limits our ability to interpret the results.

Appendix Table D reports these results. We find evidence that controlling for child fixed effects (and thus time-invariant parental characteristics) does not eliminate the effects of income, although the effects are clearly smaller and less significant. The estimated pattern is suggestive evidence that income is not simply proxying for parental non-cognitive skills rather than of family resources. This result is consistent with the limited role of parental schooling in our core estimates.

\section{Conclusion}

In this paper, we use a recent US panel of school-aged children followed between Kindergarten and $5^{\text {th }}$ grade to examine the effects of family income on children's non-cognitive

\footnotetext{
${ }^{25}$ We thank Elaine Liu for suggesting this line of inquiry.

${ }^{26}$ One way to think about this issue is that, like sibling fixed effects models, if there are spillovers between units, the estimates will be biased. Likewise, if income in one year has an impact on future socioemotional skills, we would be capturing these within-person spillovers and thus estimating biased effects.
} 
skill development. Although economists have long examined the relationships between family circumstances and children's health and cognitive development (i.e. school performance and test scores), there is very limited research providing information examining the potential effects on a broader and complementary set of skills. We find strong evidence of the importance of this often overlooked set of outcomes.

For our national sample, we document several stylized facts. We provide evidence that children enter Kindergarten with substantial differences in non-cognitive skill endowments based on family resources. We then trace the evolution of these skill differences as children age through the $5^{\text {th }}$ grade (12 years old) and show that the disadvantages grow substantially—often doubling or tripling in magnitude over the six years of this study window. We finally assess whether these skill differences can be explained by alternative measures of income, differences in children's health, differences in parental time invariant characteristics (such as their own noncognitive skills) or differences in peer (classmate) skills. In each case, we find our results to be largely robust to these alternatives, suggesting a compelling link between family income and children's non-cognitive skill development net of these other factors that are independently associated with family income.

These results are important for understanding the intergenerational transmission of poverty or SES more generally. They suggest that beyond those outcomes already studied (health and cognitive outcomes) that family income also influences noncognitive skills. These skills are themselves important in determining an individual's success in schooling and in later employment outcomes. Noncognitive skill differences seem to be an important route by which one's family of origin influences one's future family's SES. 


\section{References}

Blau DM. (1999). The effect of income on child development. Review of Economics and Statistics 81: 261-276.

Borghans, L., Duckworth, A., Heckman, J. and B. ter Weel (2008). The Economics and Psychology of Personality Traits. Journal of Human Resources, 43(4), 972-105

Brunello, Giorgio and Martin Schlotter (2011). Non Cognitive Skills and Personality Traits: Labour Market Relevance and their Development. IZA DP No. 5743. May. in Education \& Training System

Carneiro, P., Crawford, C. and A. Goodman (2007). The Impact of Early Cognitive and Non-Cognitive Skills on Later Outcomes, CEE Discussion Paper 009

Case, Anne, Darren Lubotsky, and Christina Paxson. (2002). Economic Status and Health in Childhood: The Origins of the Gradient.” American Economic Review, 92(5): 1308-1334

Classens, Amy, Greg Duncan, and Mimi Engel. (2009). "Kindergarten Skills and Fifth-grade Achievement: Evidence from the ECLS-K.” Economics of Education Review, 28(4): 415-427

Coleman, Margo and Thomas DeLeire. (2003). “An Economic Model of Locus of Control and the Human Capital Investment Decision.” Journal of Human Resources 38(3): 701-721. 
Condliffe, Simon, and Charles R. Link. (2008). “The Relationship between Economic Status and Child Health: Evidence from the United States." American Economic Review 98(5): 1605-1618.

Coneus, K., J. Gernandt, and M. Saam (2009). Noncognitive skills, school achievements and educational dropout. Discussion Paper 09-019, ZEW,Mannheim, Germany

Crosnoe, Robert. (2006). "Health and the Education of Children from Racial/Ethnic Minority and Immigrant Families.” Journal of Health and Social Behavior 47: 77-93

Cunha, F., J. J. Heckman, L. J. Lochner and D. V. Masterov. (2006)“Interpreting the Evidence on Life Cycle Skill Formation," Eds. E.A. Hanushek and F. Welch, Handbook of the Economics of Education, 12, 697-812, Amsterdam: North-Holland.

Currie, Janet, and Mark Stabile. (2003). "Socioeconomic Status and Child Health: Why Is the Relationship Stronger for Older Children?” American Economic Review 93(5): 1813-1823.

Dooley M, Stewart J.(2007). Family income, parenting styles and child behavioural-emotional outcomes. Health Economics 16: 145-162.

Fletcher, Jason M. (2012). "The Effects of Personality Traits on Adult Labor Market Outcomes: Evidence From Siblings" Journal of Economic Behavior and Organization 
Fletcher, Jason M. and Barbara L. Wolfe. (2014). "Increasing Our Understanding of the HealthIncome Gradient.” Health Economics

Gresham, F., and Elliot, S. (1990). Social skills rating system. Circle Pines, MN: American Guidance Services, Inc.

Grossman, Michael. 1972. "On the Concept of Health Capital and the Demand for Health." Journal of Political Economy 80(2): 223-255.

Gupta, ND, and Marianne Simonsen, 2010. "Non-cognitive child outcomes and universal high quality child care" Journal of Public Economics, 94(1-2) 20-43.

Hair, N, J. Hansen, B Wolfe and S Pollak 2015 JAMA Pediatrics

Heckman J, (1999), Policies to Foster Human Capital, NBER Working Paper 7288

Heckman, J.J. (2000). "Policies to foster human capital”. Research in Economics 54 (1), 3-56.

Heckman J. 2008. Role of income and family influence on child outcomes. Annals of the New York Academy of Science 1136: 307-323.

Heckman, J. J. and Y. Rubinstein. (2001)“The Importance of Noncognitive Skills: Lessons from the GED Testing Program,”. American Economic Review, 91(2), 145-149. 
Heckman, J., Stixrud, N. and S. Urzua (2006). The Effects of Cognitive and Noncognitive Abilities on Labor Market Outcomes and Social Behavior. Journal of Labor Economics 24 (3), $411-48$

Heckman, J, Seong Hyeok Moon, Rodrigo Pinto, Peter Savelyev, Adam Yavitz (2010). Analyzing Social Experiments As Implemented: A Reexamination Of The Evidence From The HighScope Perry Preschool Program. Quantitative Economics. 1, 2 (November).

Judge, Timothy A. and Charlice Hurst. (2007). "Capitalizing on One's Advantages: Role of Core Self-Evaluations." Journal of Applied Psychology 92(5): 1212-2

Khanama, Rasheda, Hong Son Nghiemb, and Luke B. Connelly. (2009). "Child Health and the Income Gradient: Evidence from Australia." Journal of Health Economics 28(4): 805-817.

Knudsen, E.I. (2004). "Sensitive periods in the development of the brain and behavior". Journal of Cognitive Neuroscience 16 (1), 1412-1425.

Knudsen, E.I., Heckman, J.J., Cameron, J., Shonkoff, J.P. (2006). "Economic, neurobiological, and behavioral perspectives on building America's future workforce". Proceedings of the National Academy of Sciences 103 (27), 10155-10162. 
Manski, Charles. (1993). "Identification of Endogenous Social Effects: The Reflection Problem" Review of Economic Studies, 60:531-42.

Morgan, Paul L., George Farkas, and Qiong Wu. (2009). "Kindergarten Predictors of Recurring Externalizing and Internalizing Psychopathology in the Third and Fifth Grades." Journal of Emotional and Behavioral Disorders, 17(2): 67-79

Murasko, Jason E. (2008). "An Evaluation of the Age-Profile in the Relationship between Household Income and the Health of Children in the United States." Journal of Health Economics 27(6): 1489-1502.

Neidell, Matthew and Jane Waldfogel. (2011). "Cognitive and Non-Cognitive Peer Effects in Early Education." Review of Economics and Statistics 92(3).

Propper, Carol, John Rigg, and Simon Burgess. (2007). "Child Health: Evidence on the Roles of Family Income and Maternal Mental Health from A UK Birth Cohort." Health Economics, 16: $1245-1269$

Savelyev, Peter (2012). "Conscientiousness, Education, and Longevity Of High-Ability Individuals." Vanderbilt University Working Paper. February 17.

Suomi, S.J. (1999). "Developmental trajectories, early experiences, and community consequences: Lessons from studies with rhesus monkeys". In: Keating, D.P., Hertzman, C. 
(Eds.), Developmental Health and the Wealth of Nations: Social, Biological, and Educational Dynamics. Guilford Press, New York, pp. 185-200.

Ter Weel, Bas. (2008). "The Noncognitive Determinants of Labor Market and Behavioral Outcomes.” Journal of Human Resources. 43(4):729-37.

Violato, Mara, Stavros Petrou, Ron Gray, and Maggie Redshaw. (2011). "Family Income and Child Cognitive Development in the United Kingdom: Does Money Matters?" Health Economics,

Wolfe, Barbara, Jessica Jakubowski, Robert Haveman, Hannah Goble, and Marissa Courey. (2010). "Casino Revenue and American Indian Health: The Link between Tribal Gaming and the Health Status and Behaviors of American Indians." Mimeo, Madison, WI. 


\section{Appendix A}

$\underline{\text { Tie between non-cognitive and cognitive skills }}$

In order to gain some insight into the importance of noncognitive skills for traditionally measured measures of cognitive skills, we create a "noncognitive factor," which is calculated as the first principle component of the SRS scales described above. As expected, it loads positively on each scale except for the internalizing/externalizing measures. This non-cognitive factor thus captures the core common elements of all of the measured noncognitive skills. We then ask the role of these factors in explaining cognitive skills as captured by test scores. For test scores we also combine the reading and mathematics scores using factor analysis. We call the combination “test score factor".

In order to first establish some notion of the importance for the non-cognitive skills on future outcomes, we estimate a set of models in which the test score factor is the dependent variable and either the noncognitive test score factor (or all of the separate scores for the noncognitive factors) is included in a regression. Also included is a set of control variables such as the child's sex, age, race dummies, birth weight, each of the two parents' schooling levels when available, mother's age, and whether or not the parents were married at the time of data collection. The results using the noncognitive factor suggest a strong and statistically significant relationship between the non-cognitive factor to the test score factor. We lag the noncognitive factor in order to avoid any simultaneity issues.

The results, reported in Appendix Table A suggest the following: lagged noncognitive factors are a very important determinant of test scores. The tie is consistent over time with a coefficient between 0.26 and 0.30 , and significant at the 1 percent level in all grades. Because the factors are each standardized, the results suggest that a one-standard deviation increase in 
lagged non-cognitive skills is associated with between a $0.25-0.30$ standard deviation increase in current-period test scores. $^{27}$

But which components of noncognitive skills seem most related to test score performance? Our next results disaggregate the "non-cognitive factor" into its component parts and suggest that being independent, being eager to learn, paying attention, and being persistence are highly associated with test scores. In terms of negative skills, those most detrimental to performance on test scores are internalizing, interpersonal skills, and self-control. The latter are surprising in two respects -two of these noncognitive skills may have been expected to be positive (interpersonal skills and self control). We also find a lack of association between externalizing behavior and test scores. Even with these surprises, the estimates provide strong confirmation of the tie between noncognitive skills and cognitive skills

\footnotetext{
${ }^{27}$ Classens et al. (2009) examine longitudinal ties between these non-cognitive skills at Kindergarten and academic performance in grade 5. They show that only measures of attention are related and that Kindergarten academic performance is a better predictor of $5^{\text {th }}$ grade performance.
} 
Figure 1

Differences in the Association between Family Income and Childhood Outcomes based on Income Measure

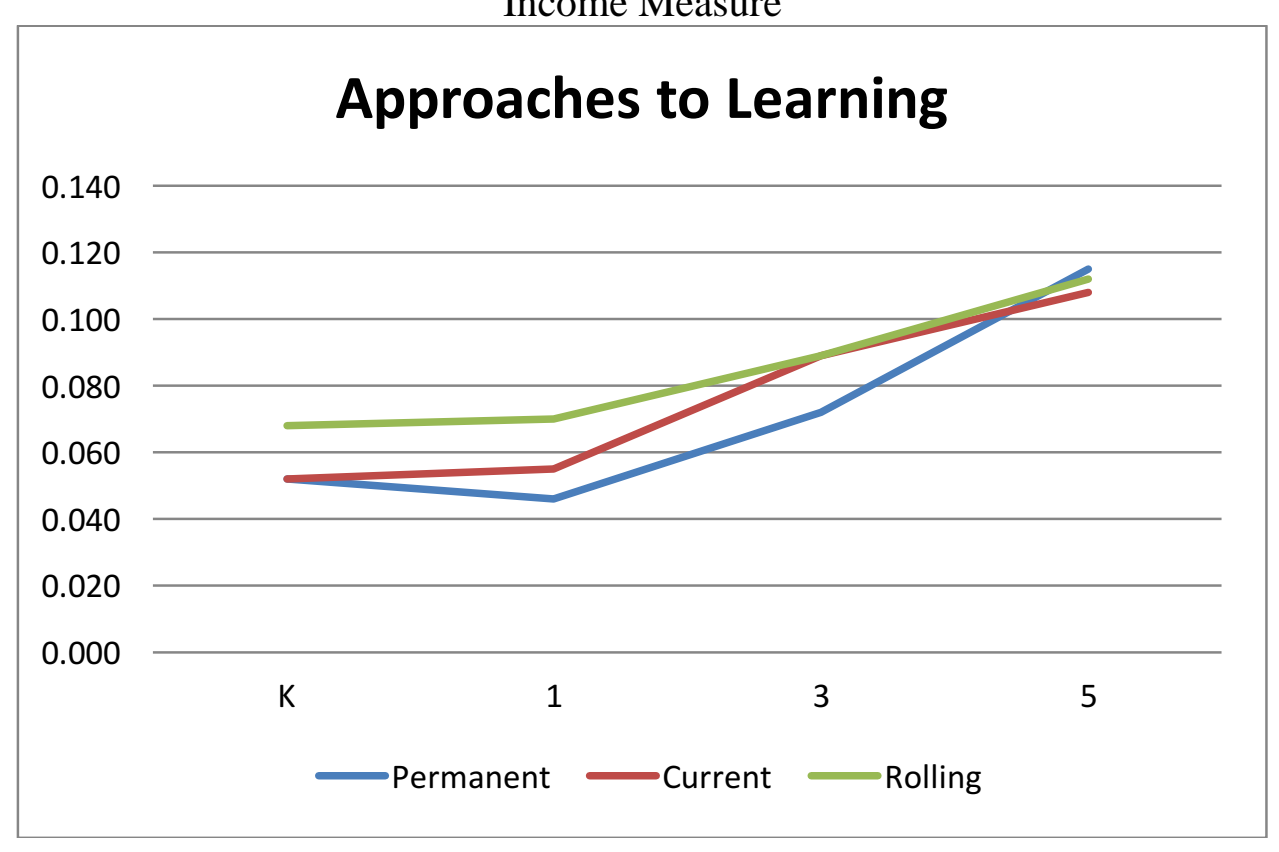


Tables

Table 1

Descriptive Statistics

ECLS-K: Grades K and 5

\begin{tabular}{|lrrrrrr|}
\hline Variable & \multicolumn{1}{l}{ Obs } & \multicolumn{1}{l}{ Mean } & \multicolumn{1}{l}{ Std. } & \multicolumn{1}{l}{ Mean } & \multicolumn{1}{l}{ Std. } \\
Approaches to Learning Scale & 7240 & 3.12 & 0.68 & 7172 & 3.05 & 0.69 \\
Self Control Scale & 7199 & 3.18 & 0.61 & 7109 & 3.22 & 0.61 \\
Interpersonal Scale & 7175 & 3.13 & 0.62 & 7041 & 3.07 & 0.65 \\
Externalizing Scale & 7212 & 1.68 & 0.64 & 7128 & 1.68 & 0.60 \\
Internalizing Scale & 7182 & 1.56 & 0.49 & 7065 & 1.65 & 0.55 \\
Special Education & 7405 & 0.04 & 0.20 & 7525 & 0.10 & 0.30 \\
Math Score & 7385 & 51.08 & 9.81 & 7491 & 51.09 & 9.76 \\
Reading Score & 7144 & 51.05 & 9.74 & 7484 & 51.09 & 9.85 \\
Poor Health & 7431 & 0.17 & 0.37 & 7525 & 0.20 & 0.40 \\
Child Health Rating & 7431 & 4.33 & 0.83 & 7525 & 4.25 & 0.85 \\
Log (Current Income) & 7404 & 10.51 & 0.96 & 7525 & 10.59 & 0.88 \\
Current Income & 7430 & 52608.33 & 51303.95 & 7525 & 55451.82 & 43492.83 \\
Permanent Income & 7431 & 52663.35 & 51807.99 & 7525 & 54063.61 & 41301.97 \\
Poverty Status & 7431 & 0.21 & 0.41 & 7525 & 0.18 & 0.38 \\
Parent Health & 7411 & 2.26 & 0.79 & 7500 & 2.27 & 0.79 \\
Parent Depressed & 7395 & 1.34 & 0.52 & 7470 & 1.35 & 0.53 \\
Male & 7431 & 0.52 & 0.50 & 7525 & 0.52 & 0.50 \\
Age (Yrs) & 7426 & 6.23 & 0.38 & 7494 & 11.37 & 0.30 \\
Black & 7431 & 0.17 & 0.37 & 7525 & 0.16 & 0.37 \\
Hispanic & 7431 & 0.17 & 0.38 & 7525 & 0.18 & 0.39 \\
Other Race & 7431 & 0.04 & 0.20 & 7525 & 0.04 & 0.21 \\
Birth weight & 7290 & 7.38 & 1.32 & 7061 & 7.40 & 1.32 \\
Maternal Education & 7431 & 13.48 & 2.45 & 7525 & 13.44 & 2.43 \\
Paternal Education & 7431 & 13.53 & 2.50 & 7525 & 13.51 & 2.47 \\
Maternal Age & 7431 & 33.77 & 6.39 & 7525 & 39.32 & 6.74 \\
Parents Married & 7431 & 0.71 & 0.45 & 7525 & 0.70 & 0.46 \\
Missing Family Information & 7431 & 0.22 & 0.42 & 7525 & 0.24 & 0.43 \\
Missing 1 Wave & 7431 & 0.21 & 0.41 & 7525 & 0.21 & 0.41 \\
Missing 2 Waves & 7431 & 0.07 & 0.26 & 7525 & 0.07 & 0.26 \\
Missing 3 Waves & 7431 & 0.02 & 0.13 & 7525 & 0.02 & 0.13 \\
Missing 4 Waves & 7431 & 0.00 & 0.05 & 7525 & 0.00 & 0.03 \\
Missing Family Information & 7431 & 0.02 & 0.15 & 7525 & 0.00 & 0.00 \\
\hline
\end{tabular}


Table 2

Descriptive Statistics

Approaches to Learning Subscales, Grades K and 5

\begin{tabular}{|c|c|c|c|c|c|c|}
\hline Variable & Obs & Mean & Std. & Obs & Mean & Std. \\
\hline Attention Scale & 7229 & 3.04 & 0.86 & 7156 & 2.95 & 0.87 \\
\hline Attention $=1$ & 7229 & 0.03 & 0.17 & 7156 & 0.04 & 0.19 \\
\hline Attention $=2$ & 7229 & 0.26 & 0.44 & 7156 & 0.30 & 0.46 \\
\hline Attention $=3$ & 7229 & 0.35 & 0.48 & 7156 & 0.35 & 0.48 \\
\hline Attention $=4$ & 7229 & 0.36 & 0.48 & 7156 & 0.32 & 0.47 \\
\hline Organized Scale & 7174 & 2.98 & 0.87 & 7140 & 2.91 & 0.95 \\
\hline Organized $=1$ & 7174 & 0.04 & 0.20 & 7140 & 0.07 & 0.26 \\
\hline Organized $=2$ & 7174 & 0.26 & 0.44 & 7140 & 0.27 & 0.44 \\
\hline Organized $=3$ & 7174 & 0.38 & 0.48 & 7140 & 0.32 & 0.47 \\
\hline Organized $=4$ & 7174 & 0.32 & 0.47 & 7140 & 0.33 & 0.47 \\
\hline Eager to Learn Scale & 7224 & 3.27 & 0.80 & 7162 & 2.98 & 0.87 \\
\hline Eager $=1$ & 7224 & 0.01 & 0.11 & 7162 & 0.03 & 0.18 \\
\hline Eager $=2$ & 7224 & 0.18 & 0.38 & 7162 & 0.29 & 0.46 \\
\hline Eager $=3$ & 7224 & 0.33 & 0.47 & 7162 & 0.34 & 0.47 \\
\hline Eager $=4$ & 7224 & 0.48 & 0.50 & 7162 & 0.33 & 0.47 \\
\hline Independent Scale & 7231 & 3.19 & 0.83 & 7168 & 3.16 & 0.81 \\
\hline Independent $=1$ & 7231 & 0.02 & 0.16 & 7168 & 0.02 & 0.15 \\
\hline Independent $=2$ & 7231 & 0.20 & 0.40 & 7168 & 0.20 & 0.40 \\
\hline Independent $=3$ & 7231 & 0.34 & 0.47 & 7168 & 0.38 & 0.49 \\
\hline Independent $=4$ & 7231 & 0.44 & 0.50 & 7168 & 0.40 & 0.49 \\
\hline Adapts Scale & 7217 & 3.12 & 0.82 & 7120 & 3.02 & 0.82 \\
\hline Adapt $=1$ & 7217 & 0.03 & 0.16 & 7120 & 0.03 & 0.17 \\
\hline Adapt $=2$ & 7217 & 0.20 & 0.40 & 7120 & 0.23 & 0.42 \\
\hline Adapt $=3$ & 7217 & 0.40 & 0.49 & 7120 & 0.42 & 0.49 \\
\hline Adapt $=4$ & 7217 & 0.37 & 0.48 & 7120 & 0.31 & 0.46 \\
\hline Persists Scale & 7222 & 3.14 & 0.87 & 7151 & 3.03 & 0.89 \\
\hline Persists $=1$ & 7222 & 0.03 & 0.18 & 7151 & 0.05 & 0.21 \\
\hline Persists $=2$ & 7222 & 0.22 & 0.41 & 7151 & 0.25 & 0.43 \\
\hline Persists $=3$ & 7222 & 0.32 & 0.47 & 7151 & 0.34 & 0.47 \\
\hline Persists $=4$ & 7222 & 0.43 & 0.49 & 7151 & 0.37 & 0.48 \\
\hline
\end{tabular}


Table 3

Initial Differences in Socioemotional Skills based on Family Income at School Entry

\begin{tabular}{|lc|}
\hline Grade & $\mathrm{K}$ \\
\hline & Approaches to \\
Log Permanent Income & $0.052^{* * *}$ \\
& $(0.018)$ \\
\hline \multirow{2}{*}{ Log Permanent Income } & Interpersonal \\
& $0.044^{* * *}$ \\
& $(0.016)$ \\
\hline \multirow{2}{*}{ Log Permanent Income } & Self Control \\
& $0.036^{* *}$ \\
& $(0.016)$ \\
\hline \multirow{2}{*}{ Log Permanent Income } & Externalizing \\
& $-0.038^{*}$ \\
& $(0.021)$ \\
\hline & Internalizing \\
Log Permanent Income & $-0.035^{*}$ \\
& $(0.015)$ \\
\hline
\end{tabular}

Robust standard errors clustered at the school-level. 1\%***, 5\%**, 10\%*. Control variables include male, age, 3 race dummies, birth weight, maternal education, paternal education, maternal age, whether parents are married and if there is missing parental information. $5^{\text {th }}$ grade longitudinal sample weights provided in the ECLSK are used. 
Table 4

Income Gradient in the Approaches to Learning Scale During K-5 ${ }^{\text {th }}$ Grade

\begin{tabular}{|c|c|c|c|c|}
\hline $\begin{array}{l}\text { Outcome } \\
\text { Grade }\end{array}$ & $\begin{array}{c}\text { Approaches to } \\
\text { Learning } \\
\mathrm{K}\end{array}$ & $\begin{array}{c}\text { Approaches to } \\
\text { Learning } \\
1\end{array}$ & $\begin{array}{c}\text { Approaches to } \\
\text { Learning } \\
3 \\
\end{array}$ & $\begin{array}{c}\text { Approaches to } \\
\text { Learning } \\
5\end{array}$ \\
\hline Log (Perm Income) & $\begin{array}{c}0.052 * * * \\
(0.018)\end{array}$ & $\begin{array}{l}0.046 * \\
(0.024)\end{array}$ & $\begin{array}{c}0.072 * * * \\
(0.027)\end{array}$ & $\begin{array}{c}0.115^{* * *} * \\
(0.027)\end{array}$ \\
\hline Male & $\begin{array}{c}-0.331 * * * \\
(0.028)\end{array}$ & $\begin{array}{c}-0.292 * * * \\
(0.030)\end{array}$ & $\begin{array}{c}-0.358 * * * \\
(0.030)\end{array}$ & $\begin{array}{c}-0.425 * * * \\
(0.027)\end{array}$ \\
\hline Age & $\begin{array}{c}0.214 * * * \\
(0.037)\end{array}$ & $\begin{array}{c}0.222 * * * \\
(0.040)\end{array}$ & $\begin{array}{c}0.134 * * * \\
(0.039)\end{array}$ & $\begin{array}{c}0.049 \\
(0.043)\end{array}$ \\
\hline Black & $\begin{array}{c}-0.079 \\
(0.053)\end{array}$ & $\begin{array}{c}-0.087 \\
(0.058)\end{array}$ & $\begin{array}{c}-0.086 \\
(0.057)\end{array}$ & $\begin{array}{c}-0.109 * * \\
(0.054)\end{array}$ \\
\hline Hispanic & $\begin{array}{c}0.058 \\
(0.036)\end{array}$ & $\begin{array}{l}0.074 * \\
(0.041)\end{array}$ & $\begin{array}{c}0.118 * * * \\
(0.042)\end{array}$ & $\begin{array}{c}0.048 \\
(0.039)\end{array}$ \\
\hline Other Race & $\begin{array}{l}-0.033 \\
(0.057)\end{array}$ & $\begin{array}{c}0.003 \\
(0.069)\end{array}$ & $\begin{array}{c}-0.002 \\
(0.072)\end{array}$ & $\begin{array}{c}0.006 \\
(0.059)\end{array}$ \\
\hline Birth weight & $\begin{array}{c}0.023 * * \\
(0.011)\end{array}$ & $\begin{array}{c}0.030 * * * \\
(0.011)\end{array}$ & $\begin{array}{c}0.002 \\
(0.012)\end{array}$ & $\begin{array}{l}-0.003 \\
(0.012)\end{array}$ \\
\hline Maternal Education & $\begin{array}{c}0.018 * * * \\
(0.006)\end{array}$ & $\begin{array}{c}0.023 * * * \\
(0.008)\end{array}$ & $\begin{array}{c}0.026 * * * \\
(0.008)\end{array}$ & $\begin{array}{c}0.015 * * \\
(0.007)\end{array}$ \\
\hline Paternal Education & $\begin{array}{c}0.017 * * * \\
(0.007)\end{array}$ & $\begin{array}{c}0.017 * * \\
(0.007)\end{array}$ & $\begin{array}{c}0.018 * * \\
(0.008)\end{array}$ & $\begin{array}{c}0.020 * * * \\
(0.007)\end{array}$ \\
\hline Maternal Age & $\begin{array}{c}0.000 \\
(0.002)\end{array}$ & $\begin{array}{l}-0.002 \\
(0.002)\end{array}$ & $\begin{array}{l}-0.001 \\
(0.003)\end{array}$ & $\begin{array}{l}-0.001 \\
(0.002)\end{array}$ \\
\hline Parents Married & $\begin{array}{c}0.120 * * \\
(0.058)\end{array}$ & $\begin{array}{c}0.137 * * \\
(0.056)\end{array}$ & $\begin{array}{c}0.188 * * * \\
(0.055)\end{array}$ & $\begin{array}{c}0.046 \\
(0.045)\end{array}$ \\
\hline Missing Family & & & & \\
\hline Information & $\begin{array}{c}-0.068 \\
(0.068)\end{array}$ & $\begin{array}{c}-0.016 \\
(0.068)\end{array}$ & $\begin{array}{c}-0.028 \\
(0.058)\end{array}$ & $\begin{array}{c}-0.088 * \\
(0.051)\end{array}$ \\
\hline Constant & $\begin{array}{c}0.699 * * \\
(0.304)\end{array}$ & $\begin{array}{c}0.342 \\
(0.386)\end{array}$ & $\begin{array}{c}0.530 \\
(0.467)\end{array}$ & $\begin{array}{c}1.082 * * \\
(0.550)\end{array}$ \\
\hline Observations & 7,078 & 6,551 & 5,907 & 6,717 \\
\hline R-squared & 0.133 & 0.116 & 0.155 & 0.184 \\
\hline
\end{tabular}

Robust standard errors clustered at the school-level. $1 \% * * *, 5 \% * *, 10 \% * .5^{\text {th }}$ grade longitudinal sample weights provided in the ECLSK are used. 
Table 5

Examination of Tie between Family Income and Sub-Scales of Approaches to Learning Measure

\begin{tabular}{|c|c|c|c|c|c|c|c|}
\hline Outcomes & $\begin{array}{c}\text { Approaches to } \\
\text { Learning }\end{array}$ & Attention & Organized & $\begin{array}{c}\text { Eager to } \\
\text { Learn }\end{array}$ & Independent & Adaptation & Persists \\
\hline Permanent Income & $\begin{array}{c}0.047^{* * *} \\
(0.016)\end{array}$ & $\begin{array}{l}0.041^{* *} \\
(0.020)\end{array}$ & $\begin{array}{l}0.045^{\star *} \\
(0.022)\end{array}$ & $\begin{array}{l}0.040^{* *} \\
(0.019)\end{array}$ & $\begin{array}{c}0.026 \\
(0.020)\end{array}$ & $\begin{array}{c}0.071^{* * *} \\
(0.021)\end{array}$ & $\begin{array}{c}0.056^{* * *} \\
(0.020)\end{array}$ \\
\hline Income X 1st Grade & $\begin{array}{c}0.002 \\
(0.020)\end{array}$ & $\begin{array}{l}-0.006 \\
(0.026)\end{array}$ & $\begin{array}{c}0.022 \\
(0.026)\end{array}$ & $\begin{array}{l}-0.000 \\
(0.025)\end{array}$ & $\begin{array}{c}0.004 \\
(0.026)\end{array}$ & $\begin{array}{l}-0.000 \\
(0.026)\end{array}$ & $\begin{array}{l}-0.001 \\
(0.027)\end{array}$ \\
\hline Income X 3rd Grade & $\begin{array}{l}0.041^{*} \\
(0.022)\end{array}$ & $\begin{array}{c}0.039 \\
(0.028)\end{array}$ & $\begin{array}{c}0.047 \\
(0.032)\end{array}$ & $\begin{array}{c}0.040 \\
(0.027)\end{array}$ & $\begin{array}{l}0.088^{* * *} \\
(0.028)\end{array}$ & $\begin{array}{l}-0.004 \\
(0.033)\end{array}$ & $\begin{array}{l}0.057^{* *} \\
(0.029)\end{array}$ \\
\hline Income X 5th Grade & $\begin{array}{c}0.061^{\star \star \star} \\
(0.022)\end{array}$ & $\begin{array}{l}0.066^{* *} \\
(0.028)\end{array}$ & $\begin{array}{c}0.082^{\star \star *} \\
(0.031)\end{array}$ & $\begin{array}{l}0.063^{\star \star} \\
(0.029)\end{array}$ & $\begin{array}{c}0.073^{\star \star *} \\
(0.028)\end{array}$ & $\begin{array}{l}0.051^{*} \\
(0.029)\end{array}$ & $\begin{array}{c}0.083^{\star \star \star} \\
(0.029)\end{array}$ \\
\hline Observations & 26,253 & 26,199 & 26,135 & 26,208 & 26,222 & 26,116 & 26,162 \\
\hline R-Squared & 0.143 & 0.115 & 0.114 & 0.095 & 0.085 & 0.072 & 0.113 \\
\hline 1st vs. 3rd Grade & 0.083 & 0.123 & 0.435 & 0.152 & 0.006 & 0.914 & 0.062 \\
\hline 1st vs. 5th Grade & 0.017 & 0.024 & 0.066 & 0.044 & 0.034 & 0.102 & 0.011 \\
\hline 3rd vs. 5th Grade & 0.376 & 0.368 & 0.301 & 0.449 & 0.614 & 0.108 & 0.402 \\
\hline
\end{tabular}

Robust standard errors clustered at the school-level. 1\%***, 5\%**,10\%*. Same controls as previous tables.

"Pays attention well". "Keeps belongings organized"; "Shows eagerness to learn new things";

"Works independently"; "Easily adapts to changes in routine"; "Persists in completing tasks". $5^{\text {th }}$ grade longitudinal sample weights provided in the ECLSK are used. P-values of F-tests are listed for differences in coefficients across grades. 
Table 6

Income Gradient in Socioemotional Skills During K-5 ${ }^{\text {th }}$ Grade

Additional Skill Domains

\begin{tabular}{|c|c|c|c|c|c|c|}
\hline Outcomes & $\begin{array}{c}\text { Self } \\
\text { Control }\end{array}$ & $\begin{array}{c}\text { Interpersonal } \\
\text { Skills }\end{array}$ & $\begin{array}{l}\text { Externalizing } \\
\text { Scale }\end{array}$ & $\begin{array}{c}\text { Internalizing } \\
\text { Scale }\end{array}$ & $\begin{array}{c}\text { Special } \\
\text { Education }\end{array}$ & $\begin{array}{c}\text { Non Cognitive } \\
\text { Factor }\end{array}$ \\
\hline Income Measure & $\begin{array}{l}0.035^{* *} \\
(0.015)\end{array}$ & $\begin{array}{l}0.036^{* *} \\
(0.015)\end{array}$ & $\begin{array}{l}-0.034^{*} \\
(0.018)\end{array}$ & $\begin{array}{c}-0.030 \text { ** } \\
(0.013)\end{array}$ & $\begin{array}{l}-0.005 \\
(0.006)\end{array}$ & $\begin{array}{c}0.064^{\star * *} \\
(0.023)\end{array}$ \\
\hline Income X 1st Grade & $\begin{array}{l}-0.007 \\
(0.018)\end{array}$ & $\begin{array}{c}0.002 \\
(0.020)\end{array}$ & $\begin{array}{l}-0.008 \\
(0.019)\end{array}$ & $\begin{array}{l}-0.042^{* *} \\
(0.016)\end{array}$ & $\begin{array}{c}0.003 \\
(0.006)\end{array}$ & $\begin{array}{c}0.004 \\
(0.027)\end{array}$ \\
\hline Income X 3rd Grade & $\begin{array}{l}0.048^{* *} \\
(0.022)\end{array}$ & $\begin{array}{c}0.027 \\
(0.022)\end{array}$ & $\begin{array}{l}-0.034 \\
(0.023)\end{array}$ & $\begin{array}{c}-0.054^{* * *} \\
(0.018)\end{array}$ & $\begin{array}{l}-0.006 \\
(0.009)\end{array}$ & $\begin{array}{l}0.069^{\star *} \\
(0.031)\end{array}$ \\
\hline Income X 5th Grade & $\begin{array}{c}0.031 \\
(0.021)\end{array}$ & $\begin{array}{l}0.042^{*} \\
(0.023)\end{array}$ & $\begin{array}{l}-0.028 \\
(0.022)\end{array}$ & $\begin{array}{c}-0.058^{* \star *} \\
(0.019)\end{array}$ & $\begin{array}{l}-0.025^{\star *} \\
(0.012)\end{array}$ & $\begin{array}{c}0.099^{* * *} \\
(0.033)\end{array}$ \\
\hline Observations & 26,064 & 25,941 & 26,134 & 25,977 & 27,970 & 25,100 \\
\hline R-Squared & 0.092 & 0.097 & 0.105 & 0.035 & 0.038 & 0.145 \\
\hline 1st vs. 3rd Grade & 0.013 & 0.277 & 0.187 & 0.513 & 0.240 & 0.041 \\
\hline 1st vs. 5th Grade & 0.104 & 0.102 & 0.365 & 0.424 & 0.011 & 0.008 \\
\hline 3rd vs. 5th Grade & 0.488 & 0.536 & 0.802 & 0.825 & 0.134 & 0.398 \\
\hline
\end{tabular}

Robust standard errors clustered at the school-level. $1 \%{ }^{* * *}, 5 \% * *, 10 \% * .5^{\text {th }}$ grade longitudinal sample weights provided in the ECLSK are used. Additional Controls: Constant, Missing Family information indicator, Maternal Age. P-values of F-tests are listed for differences in coefficients across grades. 
Table 7

Income Gradient of Socioemotional Skills

Adding Controls for Cohort Level Skills

\begin{tabular}{|c|c|c|c|c|c|c|c|c|}
\hline \multirow{4}{*}{ Approaches to Learning } & & Income & Income X & Income X & Income X & \multirow{2}{*}{\multicolumn{2}{|c|}{ Cohort Control }} & \multirow{3}{*}{ P-Value } \\
\hline & & Measure & 1st Grade & 3rd Grade & 5th Grade & & & \\
\hline & Baseline & $0.047^{\star \star \star}$ & 0.002 & $0.041^{*}$ & $0.061^{\star \star \star}$ & & & \\
\hline & Cohort Level Control & $0.035^{\star \star}$ & 0.005 & 0.031 & $0.062^{\star \star \star}$ & $0.214^{\star \star \star}$ & $(0.020)$ & 0.001 \\
\hline \multirow[t]{2}{*}{ Attention } & Baseline & $0.041^{* *}$ & -0.006 & 0.039 & $0.066^{* *}$ & & & \\
\hline & Cohort Level Control & 0.032 & -0.007 & 0.028 & $0.070^{* *}$ & $0.182^{* * *}$ & $(0.026)$ & 0.117 \\
\hline \multirow[t]{2}{*}{ Organized } & Baseline & $0.045^{* *}$ & 0.022 & 0.047 & $0.082^{* * *}$ & & & \\
\hline & Cohort Level Control & $0.041^{*}$ & 0.021 & 0.042 & $0.076^{* *}$ & $0.215^{\star \star \star}$ & $(0.028)$ & 0.898 \\
\hline \multirow[t]{2}{*}{ Eager to Learn } & Baseline & $0.040^{* *}$ & -0.000 & 0.040 & $0.063^{* *}$ & & & \\
\hline & Cohort Level Control & $0.032^{*}$ & -0.010 & 0.009 & 0.050 & $0.201^{* * *}$ & $(0.024)$ & 0.000 \\
\hline \multirow{2}{*}{ Independent } & Baseline & 0.026 & 0.004 & $0.088^{* * *}$ & $0.073^{* \star *}$ & & & \\
\hline & Cohort Level Control & 0.018 & 0.014 & $0.083^{\star \star \star}$ & $0.074^{* \star}$ & $0.179^{* * *}$ & $(0.026)$ & 0.489 \\
\hline \multirow[t]{2}{*}{ Adaptation } & Baseline & $0.071^{* * *}$ & -0.000 & -0.004 & $0.051^{*}$ & & & \\
\hline & Cohort Level Control & $0.048^{* *}$ & 0.008 & -0.006 & 0.047 & $0.294^{\star * *}$ & $(0.026)$ & 0.001 \\
\hline \multirow[t]{2}{*}{ Persists } & Baseline & $0.056^{\star * *}$ & -0.001 & $0.057^{* *}$ & $0.083^{* * *}$ & & & \\
\hline & Cohort Level Control & $0.036^{*}$ & 0.004 & 0.036 & $0.084^{\star * *}$ & $0.227^{\star \star \star}$ & $(0.026)$ & 0.000 \\
\hline \multirow[t]{2}{*}{ Special Ed } & Baseline & -0.005 & 0.003 & -0.006 & $-0.025^{\star *}$ & & & \\
\hline & Cohort Level Control & -0.005 & 0.001 & -0.014 & $-0.035^{* * *}$ & 0.003 & $(0.008)$ & 0.022 \\
\hline \multirow{2}{*}{ Self Control } & Baseline & $0.035^{\star *}$ & -0.007 & $0.048^{* *}$ & 0.031 & & & \\
\hline & Cohort Level Control & 0.024 & -0.008 & 0.023 & $0.046^{* *}$ & $0.222^{\star \star \star}$ & $(0.020)$ & 0.000 \\
\hline \multirow[t]{2}{*}{ Interpersonal } & Baseline & $0.036^{* *}$ & 0.002 & 0.027 & $0.042^{*}$ & & & \\
\hline & Cohort Level Control & 0.023 & 0.001 & 0.017 & $0.059^{* *}$ & $0.227^{\star * *}$ & $(0.020)$ & 0.000 \\
\hline \multirow{2}{*}{ Externalizing } & Baseline & $-0.034^{*}$ & -0.008 & -0.034 & -0.028 & & & \\
\hline & Cohort Level Control & -0.029 & -0.004 & -0.031 & -0.036 & $-0.121^{* * *}$ & $(0.019)$ & 0.371 \\
\hline \multirow[t]{2}{*}{ Internalizing } & Baseline & $-0.030^{\star *}$ & $-0.042^{* *}$ & $-0.054^{* * *}$ & $-0.058^{* * *}$ & & & \\
\hline & Cohort Level Control & $-0.025^{\star}$ & $-0.040^{* *}$ & $-0.050^{* * *}$ & $-0.075^{\star \star \star}$ & $-0.085^{* * *}$ & $(0.016)$ & 0.064 \\
\hline
\end{tabular}

Robust standard errors clustered at the school-level. 1\%***, 5\%**, 10\%*. Standard Errors not shown. $5^{\text {th }}$ grade longitudinal sample weights provided in the ECLSK are used. Same controls as previous tables. P-values of F-tests are listed for differences in coefficients across specifications. 
Table 8

Income Gradient of Socioemotional Skills

Adding Controls for Child Health Status

\begin{tabular}{|c|c|c|c|c|c|c|c|c|}
\hline & VARIABLES & $\begin{array}{l}\text { Income } \\
\text { Measure }\end{array}$ & $\begin{array}{l}\text { Income X } \\
\text { 1st Grade }\end{array}$ & $\begin{array}{l}\text { Income X } \\
\text { 3rd Grade }\end{array}$ & $\begin{array}{l}\text { Income X } \\
\text { 5th Grade }\end{array}$ & Health Lag & (SE) & P-Value \\
\hline \multicolumn{9}{|l|}{ Approaches to } \\
\hline \multirow{2}{*}{ Learning } & Base & $0.047^{* * *}$ & 0.002 & $0.041^{*}$ & $0.061^{* * *}$ & & & \\
\hline & Health Lag & $0.047^{* * *}$ & -0.001 & 0.031 & $0.051^{* *}$ & $0.029^{\star \star \star}$ & $(0.009)$ & 0.067 \\
\hline \multirow[t]{2}{*}{ Attention } & Base & $0.041^{* *}$ & -0.006 & 0.039 & $0.066^{* *}$ & & & \\
\hline & Health Lag & $0.041^{* *}$ & -0.008 & 0.030 & $0.056^{*}$ & $0.024^{* *}$ & $(0.011)$ & 0.021 \\
\hline \multirow[t]{2}{*}{ Organized } & Base & $0.045^{\star *}$ & 0.022 & 0.047 & $0.082^{* * *}$ & & & \\
\hline & Health Lag & $0.043^{\star *}$ & 0.017 & 0.035 & $0.071^{* *}$ & $0.042^{* \star *}$ & $(0.011)$ & 0.034 \\
\hline \multirow[t]{2}{*}{ Eager to Learn } & Base & $0.040^{\star \star}$ & -0.000 & 0.040 & $0.063^{\star *}$ & & & \\
\hline & Health Lag & $0.040^{* *}$ & -0.002 & 0.030 & $0.055^{\star}$ & 0.018 & $(0.011)$ & 0.036 \\
\hline \multirow[t]{2}{*}{ Independent } & Base & 0.026 & 0.004 & $0.088^{* * *}$ & $0.073^{* * *}$ & & & \\
\hline & Health Lag & 0.025 & 0.001 & $0.077^{* * *}$ & $0.065^{\star *}$ & $0.028^{* * *}$ & $(0.010)$ & 0.097 \\
\hline \multirow[t]{2}{*}{ Adaptation } & Base & $0.071^{\star * \star}$ & -0.000 & -0.004 & $0.051^{*}$ & & & \\
\hline & Health Lag & $0.071^{* * *}$ & -0.003 & -0.016 & 0.031 & $0.032^{* \star *}$ & $(0.012)$ & 0.040 \\
\hline \multirow[t]{2}{*}{ Persists } & Base & $0.056^{* * *}$ & -0.001 & $0.057^{* *}$ & $0.083^{* \star *}$ & & & \\
\hline & Health Lag & $0.055^{\star \star *}$ & -0.005 & 0.047 & $0.077^{* *}$ & $0.032^{\star \star \star}$ & $(0.011)$ & 0.348 \\
\hline \multirow[t]{2}{*}{ Special Ed } & Base & -0.005 & 0.003 & -0.006 & $-0.025^{\star *}$ & & & \\
\hline & Health Lag & -0.004 & 0.003 & -0.008 & $-0.026^{\star *}$ & -0.006 & $(0.004)$ & 0.018 \\
\hline \multirow[t]{2}{*}{ Self Control } & Base & $0.035^{\star *}$ & -0.007 & $0.048^{\star *}$ & 0.031 & & & \\
\hline & Health Lag & $0.035^{\star *}$ & -0.008 & $0.044^{* *}$ & 0.020 & 0.012 & $(0.008)$ & 0.180 \\
\hline \multirow[t]{2}{*}{ Interpersonal } & Base & $0.036^{* *}$ & 0.002 & 0.027 & $0.042^{*}$ & & & \\
\hline & Health Lag & $0.035^{* *}$ & 0.001 & 0.021 & 0.037 & 0.007 & $(0.009)$ & 0.118 \\
\hline \multirow{2}{*}{ Externalizing } & Base & $-0.034^{*}$ & -0.008 & -0.034 & -0.028 & & & \\
\hline & Health Lag & $-0.036^{\star *}$ & -0.008 & -0.028 & -0.022 & -0.005 & $(0.008)$ & 0.215 \\
\hline \multirow[t]{2}{*}{ Internalizing } & Base & $-0.030^{* *}$ & $-0.042^{* *}$ & $-0.054^{* * *}$ & $-0.058^{* * *}$ & & & \\
\hline & Health Lag & $-0.030^{* *}$ & $-0.041^{* *}$ & $-0.050^{* * *}$ & $-0.063^{* * *}$ & -0.011 & $(0.007)$ & 0.001 \\
\hline \multirow[t]{2}{*}{ Non Cog Factor } & Base & $0.064^{* * *}$ & 0.004 & $0.069^{* *}$ & $0.099^{* * *}$ & & & \\
\hline & Health Laq & $0.064^{* * *}$ & 0.002 & $0.057^{*}$ & $0.084^{* *}$ & $0.030^{* *}$ & $(0.012)$ & 0.117 \\
\hline
\end{tabular}

Robust standard errors clustered at the school-level. 1\%***, 5\%**, 10\%*. Standard Errors not shown. $5^{\text {th }}$ grade longitudinal sample weights provided in the ECLSK are used. Same controls as previous tables. P-values of F-tests are listed for differences in coefficients across specifications. The "health lag" variable for Kindergarten is measured as birth weight. 
Appendix Tables

Appendix Table A

The Effects of Lagged Non-Cognitive Skills on Test Scores

\begin{tabular}{|c|c|c|c|c|c|c|c|c|}
\hline Outcome & Test Score Factor & & & & & & & \\
\hline Grade & 1 & 1 & 3 & 3 & 5 & 5 & 8 & 8 \\
\hline Lagged Non Cognitive Factor & $\begin{array}{c}0.303 * * * \\
(0.010)\end{array}$ & & $\begin{array}{c}0.280 * * * \\
(0.010)\end{array}$ & & $\begin{array}{c}0.284 * * * \\
(0.010)\end{array}$ & & $\begin{array}{c}0.259 * * * \\
(0.010)\end{array}$ & \\
\hline Lagged Internalizing & & $\begin{array}{c}-0.044 * * \\
(0.018)\end{array}$ & & $\begin{array}{c}-0.067 * * * \\
(0.019)\end{array}$ & & $\begin{array}{c}-0.081 * * * \\
(0.019)\end{array}$ & & $\begin{array}{c}-0.089 * * * \\
(0.021)\end{array}$ \\
\hline Lag Externalizing & & $\begin{array}{c}0.016 \\
(0.020)\end{array}$ & & $\begin{array}{c}0.000 \\
(0.021)\end{array}$ & & $\begin{array}{l}-0.030 \\
(0.021)\end{array}$ & & $\begin{array}{l}-0.033 \\
(0.023)\end{array}$ \\
\hline Lag Attention & & $\begin{array}{c}0.124 * * * \\
(0.015)\end{array}$ & & $\begin{array}{c}0.115^{* * * *} \\
(0.016)\end{array}$ & & $\begin{array}{c}0.098 * * * \\
(0.016)\end{array}$ & & $\begin{array}{c}0.099 * * * \\
(0.020)\end{array}$ \\
\hline Lag Organized & & $\begin{array}{c}0.007 \\
(0.012)\end{array}$ & & $\begin{array}{c}-0.031 * * * \\
(0.011)\end{array}$ & & $\begin{array}{c}-0.047 * * * \\
(0.011)\end{array}$ & & $\begin{array}{c}-0.040 * * * \\
(0.013)\end{array}$ \\
\hline Lag Eager to Learn & & $\begin{array}{c}0.124 * * * \\
(0.015)\end{array}$ & & $\begin{array}{c}0.167 * * * \\
(0.015)\end{array}$ & & $\begin{array}{c}0.115^{* * *} * \\
(0.014)\end{array}$ & & $\begin{array}{c}0.108 * * * \\
(0.016)\end{array}$ \\
\hline Lag Independent & & $\begin{array}{c}0.208 * * * \\
(0.015)\end{array}$ & & $\begin{array}{c}0.247 * * * \\
(0.016)\end{array}$ & & $\begin{array}{c}0.286 * * * \\
(0.017)\end{array}$ & & $\begin{array}{c}0.178 * * * \\
(0.019)\end{array}$ \\
\hline Lag Adapt & & $\begin{array}{c}0.021 \\
(0.013)\end{array}$ & & $\begin{array}{c}0.002 \\
(0.014)\end{array}$ & & $\begin{array}{c}0.008 \\
(0.014)\end{array}$ & & $\begin{array}{c}0.002 \\
(0.016)\end{array}$ \\
\hline Lag Persist & & $\begin{array}{c}0.063 * * * \\
(0.014)\end{array}$ & & $\begin{array}{l}-0.000 \\
(0.014)\end{array}$ & & $\begin{array}{c}0.030 * * \\
(0.015)\end{array}$ & & $\begin{array}{c}0.077 * * * \\
(0.018)\end{array}$ \\
\hline Lag Self Control & & $\begin{array}{c}-0.093 * * * \\
(0.026)\end{array}$ & & $\begin{array}{c}-0.045 \\
(0.028)\end{array}$ & & $\begin{array}{c}-0.089 * * * \\
(0.026)\end{array}$ & & $\begin{array}{c}-0.083 * * * \\
(0.029)\end{array}$ \\
\hline Lag Interpersonal & & $\begin{array}{c}-0.048 * * \\
(0.023)\end{array}$ & & $\begin{array}{c}-0.113 * * * \\
(0.023)\end{array}$ & & $\begin{array}{c}-0.093 * * * \\
(0.023)\end{array}$ & & $\begin{array}{c}-0.066 * * \\
(0.026)\end{array}$ \\
\hline Observations & 8,412 & 8,412 & 7,263 & 7,263 & 6,561 & 6,561 & 5,994 & 5,994 \\
\hline R-squared & 0.325 & 0.382 & 0.356 & 0.423 & 0.361 & 0.431 & 0.358 & 0.395 \\
\hline
\end{tabular}

Robust standard errors clustered at the school-level. $1 \% \%^{* *}, 5 \% \%^{* *}, 10 \% *$. See Table 4 for control variables. $5^{\text {th }}$ grade longitudinal sample weights provided in the ECLSK are used. 
Appendix Table B: Examination of Differences in the Associations between Family Income and Childhood Outcomes based on Income Measure

\begin{tabular}{|c|c|c|c|c|c|c|}
\hline & Income & Income & Income X 1st & Income X 3rd & Income X 5th & $P$ value \\
\hline & Definition & Measure & Grade & Grade & Grade & \\
\hline \multirow[t]{4}{*}{ Approaches to Learning } & 1 & $0.047^{* * *}$ & 0.002 & $0.041^{*}$ & $0.061^{* * *}$ & \\
\hline & 2 & $0.051^{* * *}$ & 0.003 & $0.041^{*}$ & $0.055^{\star * *}$ & 0.499 \\
\hline & 3 & $0.047^{* * *}$ & 0.001 & $0.041^{*}$ & $0.058^{* * *}$ & 0.293 \\
\hline & 4 & $0.047^{\star \star \star}$ & 0.002 & $0.046^{* *}$ & $0.055^{\star \star *}$ & 0.382 \\
\hline \multirow[t]{4}{*}{ Attention } & 1 & $0.041^{\star *}$ & -0.006 & 0.039 & $0.066^{\star *}$ & \\
\hline & 2 & $0.044^{* *}$ & -0.013 & 0.036 & $0.058^{* *}$ & 0.216 \\
\hline & 3 & $0.041^{* *}$ & -0.006 & 0.039 & $0.064^{\star *}$ & 0.202 \\
\hline & 4 & $0.042^{* *}$ & -0.006 & 0.044 & $0.061^{* *}$ & 0.288 \\
\hline \multirow{4}{*}{ Organized } & 1 & $0.045^{* *}$ & 0.022 & 0.047 & $0.082^{* * *}$ & \\
\hline & 2 & $0.046^{\star \star}$ & 0.027 & 0.049 & $0.078^{* * *}$ & 0.162 \\
\hline & 3 & $0.045^{\star \star}$ & 0.022 & 0.047 & $0.081^{* * *}$ & 0.194 \\
\hline & 4 & $0.045^{* *}$ & 0.022 & 0.050 & $0.080^{\star * *}$ & 0.409 \\
\hline \multirow[t]{4}{*}{ Eager to Learn } & 1 & $0.040^{* *}$ & -0.000 & 0.040 & $0.063^{* *}$ & \\
\hline & 2 & $0.045^{\star \star}$ & 0.010 & 0.041 & $0.068^{* *}$ & 0.329 \\
\hline & 3 & $0.041^{* *}$ & 0.000 & 0.040 & $0.065^{\star *}$ & 0.117 \\
\hline & 4 & $0.041^{* *}$ & 0.001 & 0.043 & $0.061^{* *}$ & 0.293 \\
\hline \multirow[t]{4}{*}{ Independent } & 1 & 0.026 & 0.004 & $0.088^{* * *}$ & $0.073^{* * *}$ & \\
\hline & 2 & $0.032^{*}$ & 0.003 & $0.090^{* * *}$ & $0.070^{* * *}$ & 0.289 \\
\hline & 3 & 0.026 & 0.004 & $0.088^{* * *}$ & $0.071^{* * *}$ & 0.342 \\
\hline & 4 & 0.028 & 0.005 & $0.102^{* * *}$ & $0.067^{* *}$ & 0.249 \\
\hline \multirow[t]{4}{*}{ Adaptation } & 1 & $0.071^{* * *}$ & -0.000 & -0.004 & $0.051^{*}$ & \\
\hline & 2 & $0.074^{\star * *}$ & -0.004 & 0.000 & 0.041 & 0.020 \\
\hline & 3 & $0.070^{* * *}$ & -0.000 & -0.004 & 0.045 & 0.582 \\
\hline & 4 & $0.072^{* * *}$ & 0.001 & 0.010 & 0.044 & 0.237 \\
\hline \multirow[t]{4}{*}{ Persists } & 1 & $0.056^{\star \star *}$ & -0.001 & $0.057^{* *}$ & $0.083^{* * *}$ & \\
\hline & 2 & $0.063^{\star * *}$ & 0.008 & $0.058^{\star *}$ & $0.073^{* * *}$ & 0.278 \\
\hline & 3 & $0.055^{\star * *}$ & -0.001 & $0.057^{\star \star}$ & $0.078^{* * *}$ & 0.355 \\
\hline & 4 & $0.055^{\star \star \star}$ & -0.001 & $0.057^{*}$ & $0.074^{* * *}$ & 0.277 \\
\hline \multirow[t]{4}{*}{ Special Education } & 1 & -0.005 & 0.003 & -0.006 & $-0.025^{* *}$ & \\
\hline & 2 & -0.005 & 0.003 & -0.011 & $-0.020^{*}$ & 0.311 \\
\hline & 3 & -0.004 & 0.003 & -0.006 & $-0.023^{* *}$ & 0.489 \\
\hline & 4 & -0.004 & 0.003 & -0.008 & $-0.021^{*}$ & 0.151 \\
\hline \multirow[t]{4}{*}{ Self Control } & 1 & $0.035^{\star \star}$ & -0.007 & $0.048^{* *}$ & 0.031 & \\
\hline & 2 & $0.035^{\star \star}$ & -0.006 & $0.038^{*}$ & 0.022 & 0.577 \\
\hline & 3 & $0.035^{\star *}$ & -0.007 & $0.048^{* *}$ & 0.029 & 0.227 \\
\hline & 4 & $0.037^{* *}$ & -0.006 & $0.057^{* * *}$ & 0.029 & 0.254 \\
\hline \multirow[t]{4}{*}{ Interpersonal } & 1 & $0.036^{* *}$ & 0.002 & 0.027 & $0.042^{*}$ & \\
\hline & 2 & $0.035^{\star \star}$ & -0.003 & 0.024 & 0.028 & 0.502 \\
\hline & 3 & $0.035^{\star \star}$ & 0.001 & 0.027 & 0.037 & 0.454 \\
\hline & 4 & $0.036^{* *}$ & 0.002 & 0.034 & 0.032 & 0.282 \\
\hline \multirow[t]{4}{*}{ Externalizing } & 1 & $-0.034^{*}$ & -0.008 & -0.034 & -0.028 & \\
\hline & 2 & $-0.031^{*}$ & -0.006 & -0.020 & -0.015 & 0.665 \\
\hline & 3 & $-0.034^{*}$ & -0.008 & -0.034 & -0.024 & 0.294 \\
\hline & 4 & $-0.033^{*}$ & -0.008 & -0.030 & -0.018 & 0.503 \\
\hline \multirow[t]{4}{*}{ Internalizing } & 1 & $-0.030^{* *}$ & $-0.042^{* *}$ & $-0.054^{* * *}$ & $-0.058^{\star * *}$ & \\
\hline & 2 & $-0.029^{* *}$ & $-0.046^{\star * *}$ & $-0.055^{* * *}$ & $-0.040^{* *}$ & 0.569 \\
\hline & 3 & $-0.030^{\star *}$ & $-0.042^{* *}$ & $-0.054^{* \star *}$ & $-0.054^{\star * *}$ & 0.254 \\
\hline & 4 & $-0.029^{* *}$ & $-0.042^{* *}$ & $-0.055^{\star \star \star}$ & $-0.047^{* *}$ & 0.475 \\
\hline
\end{tabular}


Income Measure 1: baseline; Measure 2 is contemporaneous income; Measure 3 is 3 year rolling average; Measure 4 is 2 year rolling average. Robust standard errors clustered at the school-level (not shown). Same controls as previous tables. $5^{\text {th }}$ grade longitudinal sample weights provided in the ECLSK are used. 
Appendix Table C

Robustness Check using Balanced Samples

\begin{tabular}{|c|c|c|c|c|c|c|c|}
\hline & & $\begin{array}{l}\text { Income } \\
\text { Measure }\end{array}$ & $\begin{array}{l}\text { Income X } \\
\text { 1st Grade }\end{array}$ & $\begin{array}{l}\text { Income X } \\
\text { 3rd Grade }\end{array}$ & $\begin{array}{l}\text { Income X } \\
\text { 5th Grade }\end{array}$ & Observations & $P$ value \\
\hline \multicolumn{8}{|l|}{ Approaches to } \\
\hline \multirow[t]{2}{*}{ Learning } & base & $0.047^{\star \star *}$ & 0.002 & $0.041^{*}$ & $0.061^{* * *}$ & 26,253 & \\
\hline & balanced & $0.054^{* * *}$ & -0.003 & 0.025 & $0.053^{* *}$ & 24,228 & 0.060 \\
\hline \multirow[t]{2}{*}{ Attention } & base & $0.041^{* *}$ & -0.006 & 0.039 & $0.066^{* *}$ & 26,199 & \\
\hline & balanced & $0.051^{* *}$ & -0.014 & 0.021 & $0.056^{*}$ & 24,177 & 0.018 \\
\hline \multirow[t]{2}{*}{ Organized } & base & $0.045^{\star *}$ & 0.022 & 0.047 & $0.082^{* * *}$ & 26,135 & \\
\hline & balanced & $0.052^{* *}$ & 0.018 & 0.026 & $0.076^{* *}$ & 24,127 & 0.156 \\
\hline \multirow[t]{2}{*}{ Eager to Learn } & base & $0.040^{* *}$ & -0.000 & 0.040 & $0.063^{* *}$ & 26,208 & \\
\hline & balanced & $0.057^{* * *}$ & -0.009 & 0.014 & 0.050 & 24,186 & 0.000 \\
\hline \multirow[t]{2}{*}{ Independent } & base & 0.026 & 0.004 & $0.088^{* * *}$ & $0.073^{* * *}$ & 26,222 & \\
\hline & balanced & 0.029 & -0.002 & $0.075^{* *}$ & $0.071^{* *}$ & 24,202 & 0.121 \\
\hline \multirow[t]{2}{*}{ Adaptation } & base & $0.071^{\star \star *}$ & -0.000 & -0.004 & $0.051^{*}$ & 26,116 & \\
\hline & balanced & $0.076^{\star * *}$ & 0.004 & -0.015 & 0.036 & 24,107 & 0.239 \\
\hline \multirow[t]{2}{*}{ Persists } & base & $0.056^{\star * *}$ & -0.001 & $0.057^{* *}$ & $0.083^{* * *}$ & 26,162 & \\
\hline & balanced & $0.059^{* * *}$ & -0.005 & $0.051^{*}$ & $0.082^{* * *}$ & 24,146 & 0.933 \\
\hline \multirow[t]{2}{*}{ Special Ed } & base & -0.005 & 0.003 & -0.006 & $-0.025^{\star *}$ & 27,970 & \\
\hline & balanced & -0.000 & -0.001 & -0.011 & $-0.027^{\star *}$ & 25,792 & 0.154 \\
\hline \multirow[t]{2}{*}{ Self Control } & base & $0.035^{\star *}$ & -0.007 & $0.048^{* *}$ & 0.031 & 26,064 & \\
\hline & balanced & $0.036^{* *}$ & -0.008 & $0.044^{* *}$ & 0.028 & 24,053 & 0.974 \\
\hline \multirow[t]{2}{*}{ Interpersonal } & base & $0.036^{* *}$ & 0.002 & 0.027 & $0.042^{*}$ & 25,941 & \\
\hline & balanced & $0.033^{\star *}$ & 0.001 & 0.024 & $0.049^{*}$ & 23,953 & 0.387 \\
\hline \multirow[t]{2}{*}{ Externalizing } & base & $-0.034^{*}$ & -0.008 & -0.034 & -0.028 & 26,134 & \\
\hline & balanced & $-0.035^{* *}$ & -0.009 & -0.029 & -0.031 & 24,119 & 0.971 \\
\hline \multirow[t]{2}{*}{ Internalizing } & base & $-0.030^{* *}$ & $-0.042^{* *}$ & $-0.054^{* \star *}$ & $-0.058^{* * *}$ & 25,977 & \\
\hline & balanced & $-0.032^{* *}$ & $-0.036^{*}$ & $-0.045^{\star *}$ & $-0.060^{* * *}$ & 23,983 & 0.001 \\
\hline \multirow[t]{2}{*}{ Non Cog Factor } & base & $0.064^{\star * *}$ & 0.004 & $0.069^{* *}$ & $0.099^{* \star *}$ & 25,100 & \\
\hline & balanced & $0.073^{\star * *}$ & -0.004 & 0.053 & $0.094^{* * *}$ & 23,190 & 0.586 \\
\hline
\end{tabular}


Appendix Table D

The Effects of Current Family Income on Non-Cognitive Skills

Pooled Panel with Child Fixed Effects

\begin{tabular}{|c|c|c|c|c|c|c|}
\hline Outcome & $\begin{array}{c}\text { Non Cog } \\
\text { Factor }\end{array}$ & $\begin{array}{l}\text { Non Cog } \\
\text { Factor }\end{array}$ & $\begin{array}{l}\text { Approaches to } \\
\text { Learning }\end{array}$ & $\begin{array}{l}\text { Approaches to } \\
\text { Learning }\end{array}$ & Attention & Attention \\
\hline Fixed Effects & None & Child & None & Child & None & Child \\
\hline Log (Current Income) & $\begin{array}{c}0.067 * * * \\
(0.022)\end{array}$ & $\begin{array}{l}0.045^{*} \\
(0.027)\end{array}$ & $\begin{array}{c}0.051 * * * \\
(0.016)\end{array}$ & $\begin{array}{c}0.029 \\
(0.019)\end{array}$ & $\begin{array}{c}0.044 * * \\
(0.020)\end{array}$ & $\begin{array}{c}0.029 \\
(0.024)\end{array}$ \\
\hline Grade $=1$ & $\begin{array}{c}-0.234 * * * \\
(0.043)\end{array}$ & $\begin{array}{l}-0.105^{*} \\
(0.064)\end{array}$ & $\begin{array}{c}-0.253 * * * \\
(0.031)\end{array}$ & $\begin{array}{c}-0.142 * * * \\
(0.044)\end{array}$ & $\begin{array}{c}-0.286^{* * * *} \\
(0.039)\end{array}$ & $\begin{array}{c}-0.166 * * * \\
(0.059)\end{array}$ \\
\hline Grade $=3$ & $\begin{array}{c}-0.746 * * * \\
(0.110)\end{array}$ & $\begin{array}{l}-0.354^{*} \\
(0.183)\end{array}$ & $\begin{array}{c}-0.625^{* * * *} \\
(0.077)\end{array}$ & $\begin{array}{c}-0.301 * * \\
(0.123)\end{array}$ & $\begin{array}{c}-0.778 * * * \\
(0.096)\end{array}$ & $\begin{array}{c}-0.436 * * * \\
(0.166)\end{array}$ \\
\hline Grade $=5$ & $\begin{array}{c}-1.187 * * * \\
(0.179)\end{array}$ & $\begin{array}{l}-0.530^{*} \\
(0.309)\end{array}$ & $\begin{array}{c}-0.952 * * * \\
(0.127)\end{array}$ & $\begin{array}{l}-0.406^{*} \\
(0.208)\end{array}$ & $\begin{array}{c}-1.202 * * * \\
(0.158)\end{array}$ & $\begin{array}{c}-0.631 * * \\
(0.279)\end{array}$ \\
\hline 1st Grade X Log (Current Income) & $\begin{array}{c}0.006 \\
(0.029)\end{array}$ & $\begin{array}{l}-0.010 \\
(0.028)\end{array}$ & $\begin{array}{c}0.003 \\
(0.021)\end{array}$ & $\begin{array}{l}-0.000 \\
(0.021)\end{array}$ & $\begin{array}{l}-0.013 \\
(0.027)\end{array}$ & $\begin{array}{l}-0.022 \\
(0.027)\end{array}$ \\
\hline 3rd Grade X Log (Current Income) & $\begin{array}{c}0.067 * * \\
(0.032)\end{array}$ & $\begin{array}{c}0.040 \\
(0.032)\end{array}$ & $\begin{array}{l}0.041 * \\
(0.022)\end{array}$ & $\begin{array}{c}0.027 \\
(0.022)\end{array}$ & $\begin{array}{c}0.036 \\
(0.028)\end{array}$ & $\begin{array}{c}0.015 \\
(0.031)\end{array}$ \\
\hline 5th Grade X Log (Current Income) & $\begin{array}{c}0.081 * * * \\
(0.030)\end{array}$ & $\begin{array}{c}0.062 * * \\
(0.028)\end{array}$ & $\begin{array}{c}0.055 * * * \\
(0.021)\end{array}$ & $\begin{array}{c}0.040 * * \\
(0.019)\end{array}$ & $\begin{array}{c}0.058 * * \\
(0.026)\end{array}$ & $\begin{array}{c}0.038 \\
(0.025)\end{array}$ \\
\hline Observations & 24,284 & 24,284 & 25,392 & 25,392 & 25,341 & 25,341 \\
\hline R-squared & 0.145 & 0.684 & 0.143 & 0.655 & 0.114 & 0.619 \\
\hline
\end{tabular}

Robust standard errors clustered at the school-level. 1\%***, 5\%**, 10\%*. Same controls as previous tables. $5^{\text {th }}$ grade longitudinal sample weights provided in the ECLSK are used. 
Appendix Table D (cont'd)

The Effects of Current Family Income on Non-Cognitive Skills

Pooled Panel with Child Fixed Effects

\begin{tabular}{|c|c|c|c|c|c|c|c|c|}
\hline Outcome & $\begin{array}{c}\text { Self } \\
\text { Control }\end{array}$ & $\begin{array}{c}\text { Self } \\
\text { Control }\end{array}$ & Interpersonal & Interpersonal & Externalizing & Externalizing & Internalizing & Internali: \\
\hline Fixed Effects & None & Child & None & Child & None & Child & None & Child \\
\hline \multirow[t]{2}{*}{ Log Current Income } & $0.035 * *$ & 0.014 & $0.035 * *$ & 0.017 & $-0.031 *$ & -0.017 & $-0.029 * *$ & 0.004 \\
\hline & $(0.014)$ & $(0.019)$ & $(0.015)$ & $(0.021)$ & $(0.017)$ & $(0.019)$ & $(0.012)$ & $(0.015$ \\
\hline \multirow[t]{2}{*}{ Grade $=1$} & $-0.094 * * *$ & $-0.093 * *$ & $-0.110 * * *$ & $-0.085^{*}$ & 0.027 & 0.019 & $0.078 * * *$ & 0.039 \\
\hline & $(0.027)$ & $(0.046)$ & $(0.029)$ & $(0.047)$ & $(0.029)$ & $(0.044)$ & $(0.024)$ & $(0.046$ \\
\hline \multirow[t]{2}{*}{ Grade $=3$} & $-0.267 * * *$ & $-0.253^{*}$ & $-0.337 * * *$ & $-0.262 * *$ & $0.218 * * *$ & 0.177 & $0.258 * * *$ & 0.155 \\
\hline & $(0.067)$ & $(0.131)$ & $(0.072)$ & $(0.134)$ & $(0.074)$ & $(0.127)$ & $(0.059)$ & $(0.130$ \\
\hline \multirow{2}{*}{ Grade $=5$} & $-0.404 * * *$ & $-0.391 *$ & $-0.538 * * *$ & $-0.409 *$ & $0.270 * *$ & 0.216 & $0.373 * * *$ & 0.200 \\
\hline & $(0.111)$ & $(0.220)$ & $(0.119)$ & $(0.227)$ & $(0.119)$ & $(0.212)$ & $(0.097)$ & $(0.219$ \\
\hline \multirow[t]{2}{*}{ 1st Grade X Log (Current Income) } & -0.006 & -0.006 & -0.003 & -0.009 & -0.006 & 0.002 & $-0.046 * * *$ & $-0.035^{\prime}$ \\
\hline & $(0.020)$ & $(0.020)$ & $(0.021)$ & $(0.023)$ & $(0.021)$ & $(0.019)$ & $(0.017)$ & $(0.016$ \\
\hline \multirow[t]{2}{*}{ 3rd Grade X Log (Current Income) } & $0.038^{*}$ & 0.030 & 0.024 & 0.021 & -0.020 & -0.018 & $-0.055 * * *$ & $-0.039^{\prime}$ \\
\hline & $(0.022)$ & $(0.021)$ & $(0.021)$ & $(0.024)$ & $(0.024)$ & $(0.021)$ & $(0.018)$ & $(0.019$ \\
\hline \multirow[t]{2}{*}{ 5th Grade X Log (Current Income) } & 0.022 & 0.027 & 0.028 & 0.027 & -0.015 & -0.017 & $-0.040 * *$ & -0.029 \\
\hline & $(0.019)$ & $(0.019)$ & $(0.021)$ & $(0.021)$ & $(0.021)$ & $(0.018)$ & $(0.018)$ & $(0.017$ \\
\hline \multirow[t]{2}{*}{ Constant } & $2.456 * * *$ & $2.595 * * *$ & $2.297 * * *$ & $2.639 * * *$ & $2.086 * * *$ & $1.886 * * *$ & $2.088 * * *$ & $1.677 *$ \\
\hline & $(0.162)$ & $(0.299)$ & $(0.175)$ & $(0.306)$ & $(0.172)$ & $(0.291)$ & $(0.137)$ & $(0.294$ \\
\hline Observations & 25,207 & 25,207 & 25,090 & 25,090 & 25,275 & 25,275 & 25,128 & 25,12 \\
\hline R-squared & 0.093 & 0.594 & 0.098 & 0.577 & 0.105 & 0.665 & 0.035 & 0.485 \\
\hline
\end{tabular}

Robust standard errors clustered at the school-level. 1\%***, 5\%**, 10\%*. Same controls as previous tables. $5^{\text {th }}$ grade longitudinal sample weights provided in the ECLSK are used. 